\title{
Financial Repression in the European Sovereign Debt Crisis
}

\section{Citation}

Becker, Bo, and Victoria Ivashina. "Financial Repression in the European Sovereign Debt Crisis." Review of Finance 22, no. 1 (February 2018): 83-115.

\section{Published Version}

https://doi.org/10.1093/rof/rfx041

\section{Permanent link}

http://nrs.harvard.edu/urn-3:HUL.InstRepos:40549673

\section{Terms of Use}

This article was downloaded from Harvard University's DASH repository, and is made available under the terms and conditions applicable to Open Access Policy Articles, as set forth at http:// nrs.harvard.edu/urn-3:HUL.InstRepos:dash.current.terms-of-use\#OAP

\section{Share Your Story}

The Harvard community has made this article openly available.

Please share how this access benefits you. Submit a story.

Accessibility 


\title{
FINANCIAL REPRESSION IN THE EUROPEAN SOVEREIGN DEBT CRISIS
}

\author{
Bo Becker \\ Stockholm School of Economics \\ Victoria Ivashina \\ Harvard University and NBER
}

First draft: April 25, 2014

This draft: October 16, 2014

By the end of 2013, the share of government debt held by the domestic banking sectors of Eurozone countries was more than twice that held in 2007. Consistent with financial repression, we show that increased government bond holdings generated a crowding out of corporate lending. Firms were more likely to substitute loans with bonds when local banks owned more domestic sovereign debt and when that debt was risky. We show that direct government ownership as well as government influence through banks' boards of directors are among the channels used to exercise financial repression.

Key words: Credit cycles; Sovereign debt; Financial repression. JEL Codes: G21, G28, G30

We are grateful for the comments made by Viral Acharya, Matteo Crosignani, Mark Flannery (discussant), Ralph Koijen, Pedro Matos, Filippo Mezzanotti, José-Luis Peydró (discussant), Stefano Rossi, Erik Stafford, Sheridan Titman (discussant) and Paul Tucker. We thank seminar participants at London Business School, University of Virginia (McIntire), Stockholm School of Economics, Harvard Business School, Federal Reserve Bank of Boston, Federal Reserve Bank of New York and EFA for comments and suggestions. Erika McCaffrey, Patrick Clapp, Christine Rivera, James Zeitler and Baker Library Research Services provided assistance with data collection for this project.

Becker wishes to acknowledge support by Vinnova and the KAW Foundation. 
When country risk and sovereign bond yields rise, governments may resort to formal and informal pressures on the local financial sector to absorb new issues of government bonds; in other words, they may use a form of "financial repression." 1 If the financial sector cannot raise additional funds to purchase government debt, these acquisitions can only be made at the expense of other investments. Financial repression is not limited to the banks, but the crowding out of corporate loans can be particularly problematic since these loans cannot easily be replaced with other forms of financing. ${ }^{2}$ In this paper we show that financial repression of the banking sector was actively used by European countries during the sovereign debt crisis, and measure the impact of this repression on domestic corporate bank credit.

As illustrated in Figure 1, following the start of the global financial crisis in 2008, Eurozone countries experienced a run-up in public debt issuance. This expanding sovereign debt was increasingly absorbed by the local (i.e., belonging to the same country) banking sector (Figure 2.) ${ }^{3}$ On average, between 2010 and 2013, sovereign debt holdings of domestic banks (as opposed to foreign banks) increased by $5 \%$ of gross domestic product (GDP). Data for the early period of the crisis is scarce, but according to Eurostat, between 2007 and 2012, government debt held by the domestic financial sector increased by $13 \%$ of GDP. The aggregate data masks significant cross-country and cross-bank variation in the trajectories of local government debt holdings. The shift toward reliance on the domestic banking sector was largest for countries with the highest sovereign risk, i.e., those countries whose central governments would view financial repression - a form of domestic default - as most beneficial. For example, between 2010 and 2013, Greece, Ireland, Italy, Portugal, and Spain (the "GIIPS") saw an average increase of 19 percentage points (or nearly 30\%) in their domestic banks' share of bank-held sovereign debt.

\footnotetext{
${ }^{1}$ The term "financial repression" dates back to work by Shaw (1973) and McKinnon (1973) and comprises a range of policies that use the financial sector to redirect savings to the government. Historically, the primary mechanism of financial repression was a discriminatory tax on the part of the financial system that channeled savings toward private uses, which resulted in an artificially low cost of domestic funding for government.

${ }^{2}$ This point is backed by a large strand of literature, including seminal theoretical work by Diamond (1984, 1991).

3 Figure 2 also shows that there is substantial cross-country variation in the initial share of sovereign debt held by domestic banks. The Bruegel Dataset of Sovereign Bond Holdings, which goes back to late 1990, indicated that these differences in share levels are persistent over time and are not a result of the earlier part of the sovereign crisis (which is not picked up by the stress testing). In this paper we take this variation as a given, and instead focus on the changes in sovereign debt holdings of local financial institutions during the European sovereign debt crisis.
} 
This period, in which domestic banks increased their holdings of local sovereign debt, was also characterized by contraction in the issuance of new bank credit in Europe. ${ }^{4}$ The expansion in government debt was at least partly a response to the global financial crisis, which created general economic stress and a consequent fall in tax revenue. In this context, banks' investment opportunities - the demand for corporate loans - might have contracted, which, in turn, might have led banks to increase their holdings of sovereign debt. ${ }^{5}$ To demonstrate that sovereign debt on bank balance sheets crowds out corporate credit, we need to show a contraction in the bank credit supply to corporate borrowers. To do so, we build on Becker and Ivashina's (2014) methodology for detecting time-variation in credit conditions. This methodology is discussed in more detail in the next section, but the basic idea is that, if a given firm issues debt, any changes in its choice of debt are informative about the relative conditions of bank credit supply. If, in periods characterized by an expansion of a bank's holdings of domestic sovereign debt, more firms issuing debt choose to switch to bond financing, we infer that there was a relative shift in the cost of bank credit. To validate this inference as a measure of credit supply-similar to Becker and Ivashina's (2014) findings for the U.S. market - we show that, for a European firm, choosing loans over bonds has a pro-cyclical pattern which strongly correlates with multiple proxies of the availability of bank credit, including: survey-based measures of tightening in lending standards; aggregate corporate lending growth; banks' non-performing loans; loan allowances; stock price index; and GDP growth. Although this methodology can be only used for larger firms (with access to the bond market), the supply of bank credit to small firms is likely to experience a similar, if not larger, contraction. In this sense, the estimates provided in this paper represent a lower bound on the contraction in bank lending for a typical firm.

While, by design, the firms in our sample have a non-zero demand for debt, we need to make sure that the shift from loans into bonds is not driven by simultaneous easing of the conditions in

\footnotetext{
${ }^{4}$ See "U.K. Bank Lending to Companies Falls," The Wall Street Journal, November 25, 2013; "Italian Banks' Woes Hurt Small Firms," The Wall Street Journal, December 1, 2013; "The 'Silent Austerity' in Banking," The Wall Street Journal, January 21, 2014; "Given Them Some Credit," The Financial Times, February 19, 2014; "ECB: Private-Sector Lending Falls Again," The Wall Street Journal, February 27, 2014; "Bank's Lending to Private Sector Falls Again: ECB Data Suggests Recovery in the Euro Zone Will Remain Sluggish," The Wall Street Journal, March 27, 2014; "Irish Lending Hits Eight-Year Low," The Wall Street Journal, March 31, 2014; "U.K. mortgage approvals dip in February, business lending contracts again," Reuters, March 31, 2014.

${ }^{5}$ To explain the increased "home bias" in holdings of sovereign debt-in the absence of any pressure from the local government, i.e., financial repression — there would need to be some additional frictions.
} 
the bond market. Because some of our results use cross-country and cross-bank variations in the expansion of sovereign debt, eased conditions and an expansion in bond supply would need to be country-specific. These shifts would also have to positively correlate with the expansion of local banks' holdings of government debt. We find just the opposite: in absolute terms, bond market conditions actually undergo tightening in such periods. In relative terms, we do not observe easing of bond market conditions for countries with rising sovereign debt risk. This allows us to interpret firms switching from loans to bonds as a measure of difficulties in securing new bank loans.

Between 2007 and 2013, European countries expanded their public debt, which was increasingly absorbed on the balance sheets of the domestic banking sector. This absorption led to a drop in the local supply of loans to large corporate issuers, as reflected in their increased propensity to switch from loan to bond financing. It is worth noting that the contraction in the loan supply in the latter part of the sovereign debt crisis - the period between the second Greek bailout and 2013:Q2 (the end of our sample) — is nearly three times larger than the contraction in loan supply that followed the period from Lehman Brothers' collapse through the first Greek bailout (Figure 3). This is consistent with a prolonged and aggravated economic downturn triggered by "the vicious cycle of banks hurting sovereigns and sovereigns hurting banks."6

Financial repression affects only the domestic sector: it is a forced home bias in banks' holdings of sovereign debt. As in the theoretical framework proposed by Acharya and Rajan (2013), this is the mechanism through which governments build debt capacity and effectively impose a tax on corporations. Cross-country variation in financial repression is core to the interpretation of our result. Centralized, cross-country policy actions or regulatory measures cannot explain our finding. For example, Basel II and Basel III rules assign zero risk-weight in calculating capital requirements for all OECD government bonds, regardless of whether those bonds are denominated in the issuing country's own currency. For the Eurozone, whose members are members of the $\mathrm{OECD}^{7}$, Basel rules therefore do not favor home-country debt. ${ }^{8}$

\footnotetext{
6 "Global Challenges in 2012," statement by International Monetary Fund Managing Director Christine Lagarde January 23, 2012. See Bolton and Jeanne (2011) and Cooper and Nikolov (2014).

${ }^{7}$ Except Cyprus and Malta, which are not important to our analysis. Latvia joined the Euro zone on January 1, 2014, after the end of our data sample.
} 
Similarly, our finding is different from the work analyzing risk-shifting by Eurozone banks in the context of the sovereign debt crisis. Acharya and Steffen (2012), Popov and Van Horen (2014), and Drechsler et al. (2013) find that European banks were more likely to purchase risky sovereign debt using funding provided by European Central Bank (ECB). However, the ECB's lending facility set collateral haircuts based on the nature of the collateral (the issuing country's credit rating), and not based on the counterparty. As such, it cannot explain the relative increase in the domestic share of bank-held sovereign debt; i.e., it cannot explain why Italian banks increasingly bought Italian debt while Spanish banks increasingly bought Spanish debt. Furthermore, risk-shifting (with or without home bias) has a distinct cross-sectional prediction: weaker, less capitalized banks are more likely to pursue risk-shifting behavior. This is not necessarily the case for financial repression. Indeed, we find that, across large banks, there is little correlation between a bank's health and its relative preference for domestic sovereign debt.

The low empirical correlation between banks' risk and their holdings of domestic sovereign debt is also helpful in addressing whether shocks to banks' balance sheets can explain increased demand for local sovereign debt. In addition, we show that the effect we identify is distinct from an increased demand for safe assets. We also show that trend in accumulation of risky domestic sovereign debt in the banking sector seems to generalize to insurance and pension sectors. This suggests that a liquidity shock, which is more characteristic of banking, is unlikely to be the underlying cause of the documented effect.

There are multiple channels through which governments can exercise pressure on their domestic banking sectors. Increased investment in home-country sovereign bonds could be explained by the expectation that bailout mechanisms will be national, and will favor those banks that hold home country sovereign debt. This is consistent with findings that home bias in sovereign debt holdings intensifies in times of economic distress. We find no relationship between banks' health and their propensity to buy local sovereign debt, which suggests that financial repression likely is not mainly operating through an implicit bailout guarantee. Instead,

\footnotetext{
${ }^{8}$ See "Squaring the Eurozone's Vicious Circle," by Lucrezia Reichlin and Luis Garicano, Project Syndicate, January 27, 2014. Another useful reference for capital treatment of sovereign debt is "Treatment of Sovereign Risk in the Basel Capital Framework," Bank for International Settlements, December 8, 2013, available at www.bis.org/publ/qtrpdf/r_qt1312v.htm.
} 
we find that government control through a direct equity holding and board seats is positively correlated with the spread of financial repression.

Although financial repression policies are traditionally associated with developing countries, Reinhart and Sbrancia (2011) show that such practices were the norm for many advanced economies for over thirty years following the end of World War II. In this paper we provide evidence of the use of financial repression by ailing European countries during the worst postwar economic recession and show the negative consequences of such behavior.

\section{Methodology and Data}

\section{A. Methodology: Mechanics}

During the European sovereign debt crisis, much of the public debt issued by governments was purchased by local banking sectors. We want to examine whether, over this period, banks that took on more domestic government debt did so at the expense of lending. In other words, was the reduction in loan volumes was driven by contraction in credit supply caused by the pressure to buy local government debt, and not by contraction in credit demand? To measure movements in bank credit supply over time, we build on the methodology proposed by Becker and Ivashina (2014). This methodology suggests that substitution from bank credit to public debt is indicative of a relative contraction in bank credit supply. ${ }^{9}$ By only sampling firms that issue new debt (either bonds or loans), we infer that all of the firms in our sample have non-zero demand for debt. As in Becker and Ivashina (2014), we examine the choice of debt at the firm level with firm-fixed effects, thus addressing potential concerns about compositional changes in the set of firms raising debt (as long as firm characteristics stay constant). This addresses the concern raised by Kashyap and Stein (2000) that using aggregate relative issuance of different types of debt may miss systematic time variation in the composition of firms that are raising finance (e.g., large, stable firms with access to the bond market issue more newly-available credit in bad times than their smaller, less stable competitors do).

In our main regressions, the dependent variable is the quarterly indicator of the debt choice $\left(L_{i t}\right)$ which is equal to 1 if a firm $i$ receives a bank loan, and 0 if a firm issues a bond in a given

\footnotetext{
${ }^{9}$ Note that this research design does not require perfect substitutability between public debt and bank loans. If substitutability is low, the tests will lack power.
} 
quarter $t$. The sample excludes any firm-quarter where no debt was raised. The basic estimated equation takes the following form:

$$
L_{i t}=c_{i}+\beta S_{I t}+e_{i t}
$$

where $c_{i}$ are firm fixed effects (within the firm time-invariant effect); $S_{I t}$ is a time-series measure capturing government debt held by the banks in country $I$ (the home country of company $i$ ) in quarter $t$. Inclusion of firm fixed effects, $c_{i}$, is core to the identification of movements in bank credit supply. The coefficient of interest, $\beta$, can be identified only if individual firms switch between loans and bonds. Due to firm-fixed effects $\left(c_{i}\right)$, including non-switchers in the sample - i.e., firms that only issue one type of debt — brings the coefficient of interest $(\beta)$ toward zero, regardless of the type of debt that they issue. To reduce this bias, the sample is limited to firms that issued bonds and loans over the period of our sample.

Our goal is to measure relative rise in the cost of bank debt. Because the loan price $\left(r_{l}\right)$ is not observable when no loan was raised, we imply movement in the relative cost of bank debt $\left(r^{l}-r^{b}\right)$ from firms' observable decisions about the source of new debt. The quarterly indicator of the debt choice $\left(L_{i t}\right)$ can be written as:

$$
L=\left\{\begin{array}{l}
1 \text { if } F\left(r^{l}-r^{b}\right) \geq \alpha \\
0 \text { if } F\left(r^{l}-r^{b}\right)<\alpha .
\end{array}\right.
$$

As in Kashyap, Stein and Wilcox (1993), F(.) is a decreasing function of the price difference of bonds and loans, but it may also reflect the fact that loans have "relationship" benefits. Equation (2) highlights that while the change in relative cost of loans and bonds, $\left(r^{l}-r^{b}\right)$, is continuous, the observable outcome - debt choice - is discrete. Some firms in our sample will continue to obtain bank credit despite the fact that loans become more expensive for them, meaning we will miss changes in bank credit conditions. This makes it harder for us to find the evidence that we are looking for.

Similarly, the "true" demand for credit is not observable; implicitly, we are using our sample restriction to ensure that all observations in our sample represent firm-quarters with non-zero demand for debt. We know for certain that a firm that issues a loan or a bond has a non-zero demand for credit, but the methodology misses firms with non-zero demand for debt that cannot 
get a loan or a bond - i.e., firms facing the most severe supply constraint - when private credit is crowded out by government debt. ${ }^{10}$ Such observations would make our case stronger; thus, missing these cases in our sample biases the estimate of $\beta$ toward zero (against our findings).

\section{B. Methodology: Validity of assumptions}

The methodology is designed to measure fluctuations in the relative cost of bank debt $\left(r_{i}^{l}-r_{i}^{b}\right)$, but we are interested in bank credit contraction (i.e., an increase in $r_{i}^{l}$ ). Because we rely on country-specific variation in debt-substitution behavior, we implicitly assume that country-level bond-market conditions-as measured by yield spread-are not negatively correlated with signs of financial repression, that is, $d r_{i}^{b} / d S_{I T} \geq 0$. Through the period of the sovereign debt crisis, overall conditions of bond supply in the Eurozone may have eased as a result of ECB cutting its benchmark rate to record low levels, but this cannot explain the crosscountry variation in propensity to switch from loans into bonds. To give a concrete example, for an expansion in bond supply to explain our finding that Greek firms turn to the bond market for new credit at the time of the sovereign debt crisis, it would need to be the case that Greek firms face a reduction in the cost of issuing public debt among the European companies just as Greek sovereign debt - and its country risk-increases. This is exactly the opposite of the finding in Almeida, Cunha and Ferreira (2014) who show that bond issuers are negatively affected by sovereign downgrades. In absolute terms, if the cost of bonds reflects a country risk premium, the cost of bonds should be rising as both sovereign debt and its riskiness are increasing. Figure 4 shows that bond yield spreads for European corporate issuers were highest in the countries most affected by the sovereign debt crisis. Moreover, given that financial repression affects the banking sector as well as traditional bond investors like pension funds and insurance companies, the expansion of sovereign debt is likely to depress both the domestic supply of bank debt and of bonds. $^{11}$

\footnotetext{
${ }^{10}$ Because of the firm-fixed effect, this is only a concern for firms that a) use both types of debt over the span of our sample and b) only drop out of the sample in periods of financial repression.

${ }^{11}$ Given the focus on loan supply, we could include firms that issue debt in a foreign bond market. However, for reasons listed above, we constrain the sample to local bond issues - which comprise a significant part of the overall bond issuance. This is consistent with the following observation by Deutsche Bank: " $(C)$ ompanies which have most reason to replace loans from their home countries' weak banks with corporate bond funding are mostly headquartered in countries where economic prospects are weak. Put differently, while most European companies
} 
The second assumption underlying our interpretation of the empirical results is that our sample firms' preference, or demand, for a particular type of debt does not shift from loans toward bonds in times of crisis. In other words, we assume that it is not the case that Greek firms favor bonds over loans - for reasons other than credit conditions - as the country sovereign debt crisis escalates. This is consistent with the standard prediction that in economic downturns, firms are likely to prefer bank debt because of its advantages in monitoring and renegotiation. Becker and Ivashina (2014) provide a discussion of the plausibility of a range of alternative explanations that relate to the countercyclical shift in demand for bonds.

\section{Sample}

The benchmark sample consists of non-financial European firms (excluding SIC codes 6000 to 6999) that issued loans and bonds between 1996 and 2013:Q2. We look at substitution between term loans (installment loans as opposed to revolving line) and bonds. ${ }^{12}$

Our firm-level data on bonds comes from Thomson Reuter's SDC Platinum database. We exclude convertible bonds, mortgage- and asset-backed bonds, and preferred stock (which appear under bonds in SDC). To be sure that we are not picking up shifts in bond supply, our benchmark results include only local bond issuance, excluding those labeled "Foreign Private" or "Foreign Public" as well as those issued in non-EU countries (i.e., notably, those issued in the U.S.). We also drop bond issues by foreign subsidiaries. ${ }^{13}$ The median bond issue in our sample is equivalent to $\$ 250$ million, and the mean is equivalent to $\$ 541$ million. The median maturity of bonds is 5.1 years and the average is 5.8 years; the average is slightly shorter at end of our sample. Less than $10 \%$ of bonds in our sample have maturities of two years or less.

Firm-level data on term loans issuance is compiled from two different sources: (i) Thomson Reuters' DealScan database of syndicated loans, and (ii) CapitalIQ. To make sure that we analyze similar forms of debt, we look at bonds and term loans rather than revolving credit lines,

tapping corporate bond markets are presumably multinational, they still have a home bias and are thus heavily exposed to their respective home economy." See "Corporate Bond Issuance in Europe," DB Research, January 31, 2013.

${ }^{12}$ A revolving line would be comparable to commercial paper, but we do not observe commercial paper issues for European firms. Becker and Ivashina (2014) find that in the U.S. data, revolving loans and commercial paper produce similar results to those obtained using term loans and bonds with this methodology.

${ }^{13}$ All our results are similar if we retain all bonds. 
since a revolving line is unlikely to be a close substitute for a bond. Approximately $74 \%$ of loans in the sample are from Dealscan and the remainder comes from CapitalIQ. DealScan tracks new issuance of large loans; the median loan size in our sample is equivalent to $\$ 476$ million, and the mean is equivalent $\$ 1,282$ million. ${ }^{14}$ CapitalIQ reports bank loan balance by type of loan (term loans and revolving lines) on an annual basis. We infer that a new term loan has been issued when the balance of term loans increases from one report to the next. This procedure will miss new term loans which are not associated with an increase in loans outstanding. Additionally, we are unsure in which quarter a loan was issued. We have tried a number of approaches in our regressions to evaluate the sensitivity of our findings to this issue, including randomizing quarter assignment, assigning all CapitalIQ loans to a particular quarter, or simply analyzing the data at an annual frequency. All these approaches give similar results to the ones reported here, which spread loans evenly across quarters.

One important insight of our paper is that it identifies financial repression of banks as a specific channel that leads to the crowding out of corporate loans. For this reason we focus on loans made by local banks, where the location of the bank is determined by its headquarters as reported in DealScan. (For loan data from CapitalIQ, we assume that loans are local.) DealScan primarily covers syndicated loans and as such involves several lenders. All loans in our sample include at least one participating local lender in the lending syndicate, and roughly $60 \%$ of all loans in our sample have a local bank as one of the lead or co-lead lenders.

The data used in our analysis is organized as a panel of firm-quarter observations. Multiple loan issues in the same quarter are counted as one, and we count bond issues the same way. We define the dependent variable for our regressions (bank credit) as one if a firm issues a new term loan but no bonds, and as zero if it issues a bond but no term loans. We exclude any quarters with issuance of both types of debt (2,507 firm-quarters). ${ }^{15}$

\footnotetext{
$1491 \%$ of loans in the Eurozone and $30 \%$ of loans in the rest of Europe are denominated in Euro. Here all amounts are converted to dollars using issue date spot exchange rates. The variable of interest for us is the choice of debt (a dummy), as opposed to the issue amount.

${ }^{15}$ An alternate way of dealing with such observations is to set the dependent variable equal to the share of new debt that comes from bank loans, or when no amounts are available, the number of shares. This increases our sample size by around a fifth, but doesn't change our results in any important way.
} 
Table 1 summarizes the composition of the sample by country and by year. Our starting sample has 8,477 firm-quarters. (Since firm quarters where no new debt was issued are excluded, the panel is unbalanced.) Italy and Germany have the lowest incidence of bank debt issuance; $26.5 \%$, and $32.0 \%$, respectively, of their debt issues were bank loans. As reported in Becker and Ivashina (2014), 32.3\% of U.S. firms issued bank debt over the same period. Some of the variation at the high end of the bank debt issuance spectrum might be driven by a small number of observations; excluding these outliers, approximately 55-60\% of firms issuing new debt choose bank debt. We define explanatory variables in later sections.

\section{The Cyclicality of European Bank Lending}

We start by validating a connection between loan and bond substitution and common proxies of bank lending conditions. The results are reported in Table $2 .{ }^{16}$ We use six different proxies:

Tightening in lending standards is a survey-based variable collected by central banks, which is available for eleven Eurozone countries in our sample. A higher value indicates that more banks report tighter credit standards (contraction in bank credit). For six countries, the data is available from 2003 onward; for two other countries, that data is available only later. ${ }^{17}$ This data limitation explains the relatively small size of the sample in specification (1). The surveys' data is not always methodologically comparable across countries, but this is less critical given that we focus on debt issuance choices within firms.

The next three variables are constructed using Bankscope, and use bank balance-sheet information. The first, Aggregate lending growth, is measured as a four-quarter rolling-window growth in outstanding loans for all banks in a country. The Non-performing loans variable is based on realized losses and is defined as the ratio of non-performing loans to total loans, also for the entire banking sector. Loan allowances, a forward-looking measure of bank-portfolio quality, is defined as the ratio of loan allowances to total loans. We use asset-weighted averages to consolidate the data across different banks within a country by quarter. Both measures of bank

\footnotetext{
${ }^{16}$ All results estimated using ordinary least squares (OLS). Using logit or probit regressions does not affect our conclusions.

${ }^{17}$ More information about country-level reporting can be found at http://www.ecb.europa.eu/stats/money/surveys/lend/html/index.en.html.
} 
portfolio quality should be negatively associated with bank-credit conditions: a higher value is likely to be associated with a contraction in bank-credit supply.

The last two variables, GDP growth and Bank stock-index, are based on models including those of Bernanke and Gertler (1989), Holmström and Tirole (1997), Kiyotaki and Moore (1997), and Diamond and Rajan (2005). Stronger economic growth — as measured by either of the proposed proxies - is predicted to be associated with an expansion of bank credit. GDP growth is real change in per capita gross domestic product, at quarterly frequency (but relative to the year prior to avoid seasonality), collected from the Eurostat website. We form a stock price index of domestic banks in each country (equally weighted), and we use the log of the stock index as an independent variable.

In line with results for the U.S. reported in Becker and Ivashina (2014), we find strong cyclicality of substitution from loans into bonds in periods that should be characterized by low credit supply. More firms switch from loans to bonds in periods when a large percentage of banks are tightening credit standards, bank credit growth is low, balances of non-performing loans and loan allowances are large, economic growth is low, and stock prices are depressed. The signs are as predicted, and all coefficients are statistically significant at the conventional levels. The coefficient estimate of 1.02 for GDP growth implies that a one-standard-deviation decrease in GDP growth is associated with a 2-percentage-point decrease in probability that a firm gets a loan, conditional on receiving debt financing (a 5.3\% decrease over the sample mean). Bank stock prices are also positively linked with new corporate debt being issued as bank loans rather than bonds. A $50 \%$ increase in the stock price of domestic banks is associated with a 1.6percentage-point increase in the fraction of new debt issued as loans.

The result we obtain by using survey-based tightening in lending standards (specification (1)) is particularly interesting because this is the most direct measure of credit conditions. Furthermore, this only includes Eurozone countries. Given that member countries do not have national currencies, the result cannot be explained by cross-country variation in monetary policy.

\section{The Effect of Domestic Sovereign Debt Holding on Bank Lending}

\section{A. Results}

Our first result establishes that a contraction in the corporate loan supply is a byproduct of higher bank investment in domestic sovereign bonds during periods that are likely to be characterized by financial repression. The most direct test is to look at the sovereign debt 
holdings of domestic banks and firms' debt issuance; these results are reported in Table 3, specifications (1) through (3).

The data for bank holdings of local government debt comes from the European Banking Authority's (EBA) 2011 Stress Tests, 2011/2012 Capital Exercise, and 2013 Transparency Exercise. The information is available at the bank level and covers the period between December 31, 2010 and June 30, 2013 with semiannual frequency (four snapshots). The specific stress test variable that we look at is "Gross Direct Long Exposures (accounting value gross of specific provisions)" to domestic sovereign debt. We use a country-level value-weighted average across all banks covered by the EBA test in a given country. We consider two alternative ways to scale bank holdings of domestic sovereign debt: (i) by risk-weighted assets (RWA), and (ii) by common equity. These variables are reported as part of the stress test, so they are comparable across banks and across countries.

The result in column (1) indicates that countries where banks hold more domestic sovereign debt on their balance sheets are the countries where bank lending, as a fraction of overall debt issuance, drops the most. The economic magnitude of the effect is large: a one-standarddeviation increase in domestic sovereign exposure (14.5\%) implies a reduction in the likelihood of new corporate debt being a loan by $14.1(-0.971 * 0.145)$ percentage points, which is very large compared to the macro variables reported in Table 2.

Increasing sovereign risk and (subsequently) the attempt by governments to circumvent an increased cost of government debt are likely the important drivers of financial repression. We are interested in capturing the amount of sovereign credit risk borne by banks, not necessarily the face value of debt owned. Also, relatively safe sovereign debt can be used as collateral to raise additional funding, and therefore may not necessary be associated with a contraction in corporate lending. To incorporate sovereign risk, we look at a proxy for the loss exposure associated with banks' holdings of domestic sovereign debt: the book value of domestic sovereign debt held by banks, times the credit default swap spread (CDS) of the sovereign. The CDS data comes from Markit. CDS are a market-based measure of default risk, and capture the cost at which banks could insure themselves against sovereign default. The interaction of holdings with spreads gives us the market price of the sovereign risk held by banks (or equivalently, an estimate of expected losses under the risk neutral measure). As reported in column (2), the association between domestic sovereign debt risk and lending is significantly negative. As before, the economic 
magnitude of the estimated coefficients is large. These results are robust to scaling by either banks' RWA or common equity.

To extend our sample to a longer period, we consider two alternatives. First, we look at the Bruegel Dataset of Sovereign Bond Holdings (Merler and Pisani-Ferry, 2012). This is a crosscountry database of country-by-country sovereign bond holdings gathered from various public sources. The holding data is disaggregated by sector and specifically identifies bank holdings of sovereign debt. Annual data covers most of the European Union countries. The shortcoming of the data is its lack of cross-country comparability, due to potential differences in accounting standards used by different national authorities. For this reason, we normalize sovereign debt holdings with bank assets rather than RWA or equity, variables for which cross-country variation in accounting treatment may be higher. The coefficient estimate implies that a one-standarddeviation change in the amount of sovereign debt held is associated with an $8.5 \%(-0.564 * 0.151)$ drop in corporate lending. This is smaller than what we find with ECB data, which is consistent with (a) a smaller squeeze-out effect in bank balance sheets in the pre-crisis period, and (b) more noise in the Bruegel data. ${ }^{18}$ We next interact with CDS spreads, measuring the amount of sovereign risk rather than the face value of holdings. The coefficient estimate is negative and statistically significant, implying a similarly large economic magnitude. Realistically, the Bruegel data has to be seen as a robustness test, since the measurement of sovereign exposure is difficult. After all, the ECB stress tests were required precisely for this reason.

In the last three specifications of Table 3, we look at total-domestic and foreign-sovereign assets held by the banking sector, expressed as a percentage of total assets. The data is obtained from Bankscope, and corresponds to the annual aggregate holdings of all domestic banks. This is an alternative way of extending the sample beyond the period covered by the stress tests. A benefit of the Bankscope data is that it covers a much larger set of banks and a longer time period. Gennaioli, Martin, and Rossi (2014) find that information on sovereign holdings in Bankscope is highly comparable to the information collected through stress testing. The drawback is that Bankscope data does not distinguish between domestic and foreign sovereign debt. Specification (6) uses the full Bankscope sample, which extends back to 1997. The

\footnotetext{
${ }^{18}$ Coefficient estimates are similar when we use the quarterly version of the variable, which is available for fewer countries but at greater frequency ( 0.460 instead of 0.425$)$.
} 
coefficient is negative and significant, implying that high debt holdings of sovereign debt are associated with low loan availability for firms. Columns (7) and (8) focus on the most recent period, when sovereign debt may be more important. The coefficient is now much larger and highly significant. An interaction with CDS spreads again suggests that sovereign risk, not just the face value held, is also important. (The coefficient estimate for the period from 1997-2006, not reported, is insignificant). These findings are consistent with the results in earlier specifications, but may simultaneously pick up a general preference for sovereign debt during the European crisis, as documented in Drechsler et al. (2013). (These effects are not mutually exclusive. ${ }^{19}$ We return to this point below.)

Table 3 includes firm-fixed effects throughout, and thus we effectively control for any firm characteristics that remain constant thorough the sample period. In Table 4 we extend the results reported in Table 3 to include firm level characteristics. The specific concern is that the risk profile of the firm changes over time, which might explain the choice of debt. Our level control variables come from two sources. Specifications (1) and (4) include controls that describe the debt issued (maturity, yield-to-maturity and a dummy equal to 1 if the loan is investment grade). The reduction in the sample size is primarily due to missing pricing information for loans and absence of credit ratings (so that the investment grade identifier is missing). Specifications (2) and (5) include firm level accounting controls gathered from Thomson One, including firm size, return on assets, book leverage, property plant and equipment, and free cash flows all measures as of the fiscal year end preceding the issuance. The last two columns include both sets of controls. Conditioning on the availability of these additional control variables makes us likely to miss smaller, more financially constrained firms, which is consistent with the drop in the economic magnitude of the coefficient of interest in several of specifications. Most important, the findings reported in Table 3 appear to be robust to inclusion of this additional set of controls.

Table 3 examines how time-variation in domestic sovereign bond holdings by the banking sector in a given country affects corporate lending. But different banks in the same country might

\footnotetext{
${ }^{19}$ From the point of view of understanding financial flows to firms and private capital formation, it may be less important whether banks restrict lending in order to invest in risky sovereign bonds (risk shifting) or they are forced/incentivized by their government to buy local sovereign bonds (repression). But the distinction is important for understanding which frictions affect the credit supply.
} 
have different exposure to financial repression, and therefore may experience different pressures on their corporate lending capacity during a crisis. In Table 5 we use such bank-level variation in the holdings of domestic sovereign debt to examine the key prediction about the link between sovereign debt and corporate lending, using within-country variation. To do so we must link firms to individual banks; that is, in a given quarter we have to associate a firm with its most likely lender regardless of whether a firm is receiving a loan. We use past syndicated loan participation as an indication that a bank has a relationship with a firm. This assumption builds on the vast theoretical and empirical literature that discusses the benefits of long-standing banking relationships. In particular, Bharath et al. (2011) and Ivashina and Kovner (2011) examine the importance of repeated borrowing from the same lender for firms using the syndicated loan market. Thus, for any new credit—loan or bond - we assume that the firm and the bank have a relationship if, in the past five years, the bank was the lead or co-lead lender to the borrower.

In matching borrowers and banks, we lose several observations if firms do not have bank relationships, or if the banks in question are not included in the ECB data. To overcome this issue, we use the 1996-2013 sample to estimate the basic firm-fixed effect regression, and use the predicted residuals from this regression as the dependent variable in the analysis reported in Table 5 (2010-2013 sample).

The first three specifications reported in Table 5 are equivalent to the first three specifications in Table 3; however, in Table 5 the explanatory variable of interest is measured at the relationship bank level. When two or more banks were involved in the origination of the previous syndicated loan - around a third of firm-quarters - the firm-year appears twice in the sample, once for each bank. Given the emphasis on cross-bank variation in domestic sovereign holdings, the results in Table 5 also include bank-fixed effects. In Section IV, we discuss the specific mechanisms through which financial repression might operate; meanwhile, inclusion of bank-fixed effects helps us to rule out any (fixed) bank characteristics as potential explanations for larger exposure to domestic sovereigns and larger contractions in credit.

As before, we find an economically strong, negative relationship between individual banks' holdings of domestic sovereign debt and their relationship borrowers' propensity to receive a loan when they seek debt financing. The effect is similar in magnitude to the estimate in Table 3. In specifications (2) and (3), we look at the interaction with the CDS spread; this allows for 
riskier government bond holdings to have a bigger impact on lending. Again, we find a negative effect, although this effect is only significant in one case. In column (4), we include only firms with a single identified bank relationship. These firms are likely to be more exposed to the loan supply of their (unique) relationship bank. Indeed, the point estimate for the effect of sovereign debt is higher for this sample. Taken together, the results in Table 5 suggest that, during the financial crisis period, firms are less likely to get a loan when their relationship bank(s) are absorbing large amounts of home country sovereign debt.

\section{B. Alternative explanations}

We interpret a contraction in a firm's propensity to get a loan during periods of rising exposure of local banks - and, in particular, of relationship banks - to risky domestic sovereign debt as financial repression. However, we need to make sure that the effect that we identity is distinct from the effect of (i) risk shifting and (ii) negative shock to banks; in other words, an increase in banks' demand for local sovereign debt. (A negative shock can be either a need for recapitalization and/or a liquidity shock; we explain both below.)

\section{(i) Risk-shifting}

The risk-shifting explanation suggests that — due to the convex payoff structure of equitybank management might be seeking to increase its holdings of risky assets during periods of stress. Given the capital treatment of sovereign debt, investing in risky government securities might be particularly attractive. This type of behavior is documented by Dreschsler et al. (2013). Thus, a concern might be that the observed increase in domestic sovereign debt holdings may reflect risk shifting and not financial repression.

To compare the financial repression hypothesis to the risk-shifting hypothesis, we perform a placebo test. If European banks like to buy risky sovereign debt in order to risk-shift, and if this is associated with lower corporate lending, a stronger predictor of lending than domestic sovereign debt ought to be the sovereign debt that carries the most risk. In the period in question, the country with the riskiest sovereign debt is Greece. In fact, Dreschsler et al. (2013) specifically focus on banks' risk-shifting behavior in periods when Greek sovereign risk, measured by CDS and its credit rating (which determined the haircut applied by the ECB when sovereign was debt used as collateral) would diverge. Under the financial repression hypothesis, holdings of foreign sovereign debt are not expected to have the same effect on lending as 
holdings of domestic sovereign debt. Whereas home debt has been forced upon unwilling banks (it is a forced transfer to the state), holding foreign sovereign debt is voluntary. This is important, because it implies that home debt may be associated with missed lending opportunities, whereas other sovereign debt will not.

To distinguish the domestic and general risky sovereign debt effect we reexamine the results in Table 3 with an extra control: the holdings of Greek debt by domestic banks. (Greek firms are excluded from this sample.) The results are reported in Table 6, Panel A columns (1) and (2). Both with and without the CDS adjustment, holdings of domestic debt are negatively associated with the propensity to issue bank debt, whereas holdings of Greek debt have no effect, or even a positive effect, on the choice of debt. ${ }^{20}$

Greece is typically the country with the highest CDS spread in the period of the analysis. However, several other countries also have very high CDS spreads in some periods. Bonds from such countries would be a natural target for any bank that wished to risk-shift or take advantage of the subsidy embedded in the ECB funding facility. To generalize our result, in columns (3) and (4) of Table 6, Panel A we look at holdings of top-3 riskiest EURO-area sovereign bonds. That is, for any country, we add up holdings of sovereign bonds of the three countries with the highest spreads at the previous year-end. For example, for 2012, we use holdings of Greek, Cypriot, and Portuguese sovereign debt (the highest three CDS spreads at year end 2011). For banks from one of these countries, we use Irish debt instead (Ireland had the fourth highest CDS spread). So for Greek banks in 2012, Greek sovereign debt is domestic debt, and the sum of holdings of Cypriot, Portuguese and Irish sovereign debt is the exposure to the top-3 riskiest EURO-area countries. These results show that the effect that we measure is specific to local debt, and so our earlier findings are distinct from the risk-shifting behavior documented by Dreschsler et al. (2013).

Crosignani (2014) develops a model where highly levered banks risk-shift into domestic government bonds because of the high correlation with their other sources of revenue. The idea

\footnotetext{
${ }^{20}$ We have also run this type of "horse race" regression between holdings of Greek and home country sovereign debt in the bank-specific sample like the analysis reported in Table 5. In this setting banks' holdings of home debt also have a negative effect on the propensity of borrowers to issue loans, but holdings of Greek debt do not (outside Greece).
} 
is that in the case of domestic sovereign default (the bad state of the world), banks are protected by limited liability; and at the same time, home sovereign debt guarantees the highest payoff in the good state of the world. The testable hypothesis in Crosignani (2014) and Dreschsler et al. (2013) is that risk-shifting should be associated with less capitalized banks. In Table 6, Panel B we look at how different measures of a bank's capitalization are related to the bank's propensity to hold and grow its holdings of local sovereign debt. Capital adequacy measures come from ECB tests. CDS and ratings data is from Markit and is available for a more restricted sample of banks. The first set of results corresponds to the unconstrained sample of countries, but the emphasis is on risky countries (defined here as European countries with CDS spreads above 100 basis points as of December 2010.) The results indicate that correlations between bank health and relative preference for domestic sovereign debt overall are economically small, often of an opposite sign, and rarely statistically significant.

Another point to consider is that the underlying assumption in risk-shifting with home bias is that the local banking sector will end up in default if the government defaults on its debt. Perhaps this is the point that commands more empirical research, but at least anecdotally (e.g. Greece, Argentina), it does not appear to be the case that upon sovereign default, a country's banking sector (and especially the largest banks) gets to the state where banks no longer care about the cash flows on their portfolios. In fact, having some positive cash flows in such states might be a source of competitive advantage.

\section{(ii) Negative Bank Shock}

The small correlation between a bank's financial health and its propensity to hold domestic sovereign debt is also important in distinguishing financial repression from a capitalization shock. In a traditional bank lending channel, banks need to recapitalize. Banks can do so by injecting more capital and/or by reducing RWA. One way to lower RWA is to shift a bank's portfolio to safe (zero-weight) securities like sovereign debt. ${ }^{21}$ Our results are not explained by weaker banks which makes this alternative explanation unlikely.

\footnotetext{
${ }^{21}$ One would also need to explain what generates a home bias in this case. Note that if the pressure emanates from the local bailout mechanism, that is a mechanism of financial repression.
} 
Another explanation of the link between holdings of sovereign debt and low corporate lending posits that banks may have felt a need to increase holdings of liquid assets during the crisis period-negative liquidity shock. For example, this could happen as a buffer against liquidity needs of the bank's customers (Kashyap, Rajan, and Stein, 2002). In turn, higher demand for liquidity could have led to an increase in holdings for sovereign debt (Krishnamurthy and Vissing-Jorgensen, 2012) at the expense of the willingness to hold other assets, including corporate loans. This theory would predict that banks would hold the safest sovereign debt, and not necessary a bank's home country debt. (The prediction is thus opposite to risk-shifting.)

To distinguish our result from this alternative effect, we repeat the test above, using Germany (the lowest-risk sovereign issuer in the Euro area) and the lowest three CDS Euro area issuers (Finland, Germany and either the Netherlands or Austria, depending on the exact time). The results are reported in Table 7, Panel A. The strong negative association with domestic debt remains, while holdings of German debt have a positive association with lending in one regression and a negative one in the other. Overall, these results suggest that the sovereign debt of a bank's home country has a special role in the bank's balance sheet, where that debt tends to displace corporate lending. Other types of sovereign debt do not appear to have this effect during the European sovereign debt crisis.

We also look outside the banking sector. As mentioned before, financial repression need not be limited to the banking sector. Liquidity shocks are likely more critical for the banking sector, which has short term funding (and long term liabilities) and which issues undrawn credit lines that could be subject to a run (Ivashina and Scharfstein, 2010). Thus, if other segments of the domestic financial sector in risky countries accumulate sovereign debt, this further weakens the idea of liquidity shock to the banks as an explanation of our findings of depressed corporate loan supply during the crisis.

There is ample anecdotal evidence that struggling governments also pressured local pension funds to place their liabilities. ${ }^{22}$ The reporting of sovereign exposures of pension plans and insurance companies varies by country and by firm, and overall it is hard to assess the

\footnotetext{
${ }^{22}$ For example, see "Spain Drains Fund Backing Pensions," Wall Street Journal, January 3, 2013; "Portugal Plunders Pension Fund to Tackle Debt Cliff," Reuters, May 22, 2013; "Italy's Government Looks to Tap Pensions Funds," Wall Street Journal, October 24, 2013.
} 
decomposition of sovereign holdings in domestic and foreign debt. One exception is Portugal, for which we were able to collect a time series of domestic sovereign exposure through the country's insurance and pension regulatory agency. But although somewhat similar regulators exist in each country, domestic sovereign debt holdings are not collected in a centralized way (or were not until very recently). We also searched through annual statements of the largest insurers and pension funds in Germany, France, Spain and Italy. The results are reported in Table 7, Panel B.

As for banks, we find a pattern of accumulation of domestic government debt by non-bank financial institutions in several countries. In safer countries, this is not apparent, however. The French Public Service Additional Pension Scheme maintained its share of domestic debt as a percentage of sovereign debt between 2007 and 2012. The picture is similar for the largest German insurer, Allianz. In sharp contrast, the Spanish Social Security Reserve Fund (a state pension fund) almost doubled its holdings of domestic debt (in relative terms, and actually, by 2012, nearly triples its holding of sovereign debt in absolute terms), shifting almost its entire portfolio to national government debt. Between 2007 and 2007, Portugal's pension system increased its portfolio allocation to domestic debt by 6 percentage points (from $4 \%$ to $10 \%$ ). The rise of insurance sector's exposure to domestic debt was even more dramatic. These patterns are parallel to those observed for the banking sector, and indicate that the pressure to hold domestic sovereign debt was not attributable to shocks to individual financial firms, or even to a particular segment of the financial industry.

\section{The Mechanisms of Financial Repression}

In this section we focus on specific channels of government pressure on banks. As mentioned earlier, there are multiple mechanisms through which governments can pressure domestic banks to buy local sovereign debt. These mechanisms are likely not mutually exclusive and some of them might be too subtle to capture in the data. ${ }^{23}$ Thus, our goal is to indicate some of the

\footnotetext{
${ }^{23}$ Sorkin (2009) has examples of federal pressure on U.S. banks. For example, he suggests that Treasury Secretary Hank Paulson concluded the meeting with the CEOs of the largest U.S. banks, in which the bankers were asked to acquire Lehman Brothers' assets, by stating: "This is about our capital markets, our country. We will remember anyone who is not seen as helpful." This implies pressure from the government, but also long-term industry
} 
channels that were likely to be at play throughout the European sovereign crisis, as opposed to providing a complete picture of the channels by which governments exercise financial repression. Results in Table 6, Panel B suggest that it is unlikely that bailouts provide the primary source of motivation for the banks in our sample to buy sovereign bonds. We cannot measure future bailout expectations, but we have compared those European banks that have received bailouts to those that have not (tests not reported) and found no difference in uptake of sovereign debt (similarly, the size of bailouts did not predict sovereign debt). ${ }^{24} \mathrm{Next}$, we turn instead to more direct channels of influence over banks.

\section{(i) Government ownership}

Direct government ownership of banks has been shown to influence banks' investment decisions (e.g., Barth, Caprio, and Levine, 2001; La Porta, Lopez-de-Silanes, and Shleifer, 2002; and Sapienza, 2004). In Figure 5 we look at the relationship between the share of local banks with a government equity stake (horizontal axis) and the increase in the banks' holdings of local sovereign debt (vertical axis). We consider two alternative measures of government ownership of banks. The first measure is from the country-level survey conducted by the World Bank (see Barth, Caprio, and Levine, 2013, whose research team was instrumental to the design of this survey). The variable is the percentage of the banking system's assets in banks where the government owns no less than $50 \%$ equity. ${ }^{25}$ The data is available for several years, and we take the average of the period from 2008-2010. The second measure is from Iannotta, Nocera, and Sironi (2013), who use Bankscope data to track government ownership of banks from 2000 to 2009. They focus on European commercial banks with total assets of at least 10 billion euro in at least one fiscal year-end. The measure of government ownership is a continuous variable that measures the percentage of banking sector equity controlled by the state. Another advantage of this measure is that it predates the peak of the sovereign debt crisis.

reputation risk for the banks that refuse to succumb to this pressure, since such behavior constitutes an externality on the rest of the industry.

${ }^{24}$ We thank Sasha Steffen and Viral Acharya for generously sharing data on bailouts.

${ }^{25}$ The specific question in the 2011 survey is: "13.7.1 What percent of the banking system's assets was in banks that were government-controlled (e.g., where government owned 50\% or more equity) at the end of [2008, 2009, 2010]?”. 
The fact that the government can influence the banks does not necessarily mean that it needs to do so; only countries with rising sovereign risk are likely to use the financial repression. To show this, we condition the sample on countries with CDS spreads above 100 basis points as of December 2010. (As expected, without this constraint, the relationship between state ownership of banks and the increase in sovereign debt holdings is much weaker.) As Figure 5 illustrates, there is a positive relationship between depth of government ownership over the banking sector and likelihood that the local government debt will primarily show up on the balance sheet of domestic banks. Excluding Portugal, which appears to be an outlier, the correlation between a continuous measure of government ownership and the increase in banks' local sovereign debt holdings during the crisis is 0.72 - statistically significant at $10 \%$ level, despite a very small sample size.

(ii) Board seats

Equity ownership clearly does not capture all the mechanisms of direct control available to the government. For example, although according to the World Bank there are no Spanish banks which are majority owned by the government, it is well known that the government has considerable influence over the Spanish banking sector through the banks' boards of directors, especially savings banks or "cajas" (e.g., Santos, 2013). Similarly, Italian banks show up in the World Bank data as having zero government ownership; but among the largest bank shareholders are non-profit foundations or "fondazioni" which, in turn, are controlled by political parties. ${ }^{26}$ According to the IMF 2013 Country Report for Italy, foundations control or exercise significant influence over $30 \%$ of the banking system and are a major shareholder in four of the top-10 banks.

We collect background data on board members, as well as the year they joined or left the board for each bank in our sample, from BoardEx, compiled by Management Diagnostics Limited. Overall, we identify 148 individuals (60 different banks) that by 2011 were on the

\footnotetext{
26 "Italian Bank Foundations Under Siege on Overhaul Push," Bloomberg News, October 30,2013 gives the following description of the these foundations: "Banking foundations are a particularly Italian institution. The 88 non-profit groups, some of which trace their origins back more than 400 years, were entrusted with the ownership of Italy's banks when they were sold by governments in the 1990s. Their mandate was to support the lenders as they consolidated and gradually opened to new investors. Banks' dividends funded foundations 'charitable activities."
} 
board of directors of banks covered by the ECB stress testing and that have a current or recent (post-1998) affiliation with the government (including foundations in Italy). We distinguish between affiliation with the local and central governments as well as between members of executive and supervisory committees, but do not find these differences to be important for the interpretation of the results. We then examine the relationship between increases in sovereign debt holdings (as a share of risk-weighted assets) in the 2011-2013 period and government board representation (the time horizon is limited by data availability: at the bank level, domestic sovereign debt holdings are only known back to 2011). We demaean each variable by country, so as to identify the slope from variation between banks in the same judicial and political system. The two variables are plotted in Figure 6.

Regression lines are plotted separately for countries with high and low CDS spreads (we use spread of 100 in as the cutoff), and only the former relationship is significant. These data are consistent with financial repression determined in part by direct board representation.

\section{The Consequences of Financial Repression}

The Euro area has experienced two crisis episodes in rapid succession: first, the financial crisis that spread from the US; and second, a longer and deeper crisis associated with sovereign debt problems, which is still unresolved. In the second crisis, when sovereign debt issuance has been very challenging for many countries (yield spreads to German debt as well as CDS spreads have reached historic highs), an increasing share of newly-issued sovereign debt has been absorbed by domestic banks. This is especially true in some of the countries with the highest debt levels and the most dramatic increase in spreads, such as Greece and Italy. We show that the increase in domestic sovereign debt holdings by banks is strongly associated with a contraction in the corporate loan supply. This effect is distinct from risk-shifting or banks' responses to negative shocks to their balance sheets. Instead, consistent with financial repression, this effect is more pronounced for the banks that are influenced by the government through direct ownership or board seat possession.

In this final section of the paper we look to generalize our findings beyond the European sovereign debt crisis and to reflect on welfare implications. To do so, we examine the relationship between total domestic sovereign debt and debt choice at the firm level. The results are reported in Table 8. As before, the independent variable is the choice of debt by individual firms. The explanatory variable of interest is the total level of local government debt as a 
percentage of GDP, measured at end of the preceding year. With larger and riskier government debt, an increasing fraction of firms issuing debt switch from loans to bonds, reflecting a higher relative cost of bank credit. The result is strongest in the crisis period (2007-2013), which is the period over which rising financial repression became a concern, but barely significant in the precrisis period. This is consistent with repression, if bank acquisitions of sovereign debt in normal times are primarily voluntary and undertaken without government pressure. The estimated magnitude for the crisis period implies that a ten-percentage-point increase in the ratio of public debt to GDP predicts a 3.5-percentage-point lower likelihood of new debt being bank loans.

In specifications (7) through (9) we focus on the linearity of the effects of financial repression for highly levered countries. This builds on the idea in Reinhart and Rogoff (2009) that, beyond a certain level, public debt can be damaging to a country's economic growth. We focus on country-quarters with public-debt-to-GDP levels between 60\% (the limit specified in the European fiscal rules) and $90 \%, 90 \%$ to $120 \%$, and above $120 \%$. We find that the crowding out of bank credit is largely concentrated in country-quarters with public-debt-to-GDP levels in excess of $90 \%$. The incremental effect is positive, economically large, and statistically significant at the $1 \%$ level for country-quarters with $90 \%$ to $120 \%$ debt to GDP, and above $120 \%$ debt to GDP. This finding is consistent with the use of financial repression as an indirect form of government debt restructuring. It is also helpful for aggregate welfare assessments of our finding, given the result from a number of approaches summarized in Reinhart, Reinhart, and Rogoff (2012), which show that very high levels of public debt may have a negative effect on economic growth.

Finally, to provide a sense of the magnitude of the drop in bank credit supply to firms we run a horse race between GDP growth and sovereign debt holdings. Comparing the 2010:Q22011:Q3 (good period) to 2011:Q4-2013:Q (bad period), loan share dropped by around 16\% (cf. Figure 3). We decompose this by running a regression as in Table 3 and 4, with GDP growth capturing the regular effect of a recession, and sovereign debt holdings capturing the effect of repression. Changes in the composition of issuing firms explains none of the $16 \%$ drop, the business cycle explains $1.9 \%$, and financial repression explains $4.4 \%$. The remainder is not explained by our regressions. In other words, financial repression appears to have reduced the loan share substantially, and by much more than in a typical recession. 


\section{References}

Acharya, V., and R. Rajan, 2013, "Sovereign Debt, Government Myopia and the Financial Sector," Review of Financial Studies 26, 1526-1560.

Acharya, V., and S. Steffen, 2012, "The 'Greatest' Carry Trade Ever? Understanding Eurozone Bank Risks," Working paper.

Almeida, H., I. Cunha, and M. Ferriera, 2014, "The Real Effects of Credit Ratings: The Sovereign Ceiling Channel," Working paper.

Barth, J., G. Caprio, and R. Levine, 2001, "Banking systems around the globe: do regulations and ownership affect performance and stability?" Prudential Supervision: What Works and What Doesn't, Mishkin, F., ed., University of Chicago Press, Chicago, IL.

Barth, J., G. Caprio, and R. Levine, 2013, "Bank Regulation and Supervision in 180 Countries from 1999 to 2011," Journal of Financial Economic Policy 5, 111-220

Becker, B., and V. Ivashina, 2014, "Cyclicality of Credit Supply: Firm Level Evidence," Journal of Monetary Economics 62, 76-93.

Bernanke, B., and M. Gertler, 1989, "Agency Costs, Net Worth, and Business Fluctuations," American Economic Review 79, 14-31.

Bharath, S., S. Dahiya, and A. Saunders, 2011, "Lending Relationship and Loan Contract Terms," Review of Financial Studies 24, 1141-1203.

Bolton, P. and O. Jeanne, 2011, "Sovereign Default and Bank Fragility in Financially Integrated Economies," Working paper.

Cooper, R. and K. Nikolov, 2014, "Government Debt and Banking Fragility: The Spreading of Strategic Uncertainty," NBER Working Paper No 19278.

Crosignani, M., 2014, "Why Are Banks Not Re-capitalized During Crises? A Political Economy Explanation," Working paper.

Diamond, D., 1984, "Financial Intermediation and Delegated Monitoring," Review of Economic Studies 51, 393-414.

Diamond, D., 1991, "Monitoring and Reputation: The Choice between Bank Loans and Directly Placed Debt," Journal of Political Economy 99, 689-721.

Diamond, D. and Rajan, R., 2005, "Liquidity Risk, Liquidity Creation, and Financial Fragility: A Theory of Banking," Journal of Political Economy 109, 287-327.

Drechsler, I., T. Drechsel, D. Marques-Ibanez, and P. Schnabl, 2013, "Who Borrows form the Lender of Last Resort?" Working Paper.

Gennaioli, N., A. Martin, and S. Rossi, 2014, "Banks, Government Bonds, and Default: What do the Data Say?" Working Paper.

Holmström, B. and J. Tirole, 1997, "Financial Intermediation, Loanable Funds, and the Real Sector," Quarterly Journal of Economics, 112, 663-691.

Iannotta, G., G. Nocera and A. Sironi, 2013, "The Impact of Government Ownership on Bank Risk," Journal of Financial Intermediation, 22, 152-176.

Ivashina V., and A. Kovner, 2011, "The Private Equity Advantage: Leveraged Buyout Firms and Relationship Banking," Review of Financial Studies 24, 1141-1203.

Ivashina V., and D. Scharfstein, 2010, "Bank Lending During the Financial Crisis of 2008," Journal of Financial Economics 99, 500-522.

Kashyap, A., R. Rajan and J. Stein, 2002, ""Banks as Liquidity Providers: An Explanation for the Coexistence of Lending and Deposit-Taking," Journal of Finance, 57(1), 33-73.

Kashyap, A., J. Stein, 2000, "What Do A Million Observations on Banks Say About the Transmission of Monetary Policy?" American Economic Review, 90, 407-428.

Kashyap, A., J. Stein, and D. Wilcox, 1993, "Monetary Policy and Credit Conditions: Evidence from the Composition of External Finance," American Economic Review, 83, 78-98.

Kiyotaki, N. and Moore, J., 1997, "Credit Cycles," Journal of Political Economy 105, 211-248.

Krishnamurthy, A., and A. Vissing-Jorgensen, 2012, "The Aggregate Demand for Treasury Debt," Journal of Political Economy, 120, 233-267. 
La Porta, R., F. Lopez-de-Silanes, and A. Shleifer, 2002, "Government Ownership of Banks," Journal of Finance 57, 265-301.

McKinnon, R., 1973, Money and Credit in Economic Development, Washington DC: Brookings Institution.

Merler, Silvia, and Jean Pisani-Ferry, 2012, "Who's Afraid of Sovereign Bonds", Bruegel Policy Contribution, February.

Popov, A. and N. Van Horen, 2014, "Exporting Sovereign Stress: Evidence from Syndicated Bank Lending during the Euro Area Sovereign Debt Crisis," Review of Finance, forthcoming.

Reinhart, C. and B. Sbrancia, 2011, "The Liquidation of Government Debt," NBER Working Paper 16893.

Reinhart, C., V. Reinhart and K. Rogoff, 2012, "Public Debt Overhangs: Advanced-Economy Episodes since 1800," Journal of Economic Perspectives 26, 69-86.

Reinhart, C. and K. Rogoff, 2009, This Time is Different - Eight Centuries of Financial Folly, Princeton University Press.

Santos, T., 2013, "Antes del Diluvio: The Spanish Banking System in the First Decade of Euro," Working Paper.

Sapienza, P., 2004, "The Effects of Government Ownership on Bank Lending," Journal of Financial Economics 72, 357-384.

Shaw, E., 1973, Financial Deepening in Economic Development, New York: Oxford University Press.

Sorkin, Andrew Ross, 2010, Too Big to Fail: The Inside Story of How Wall Street and Washington Fought to Save the Financial System--and Themselves, Penguin Books. 

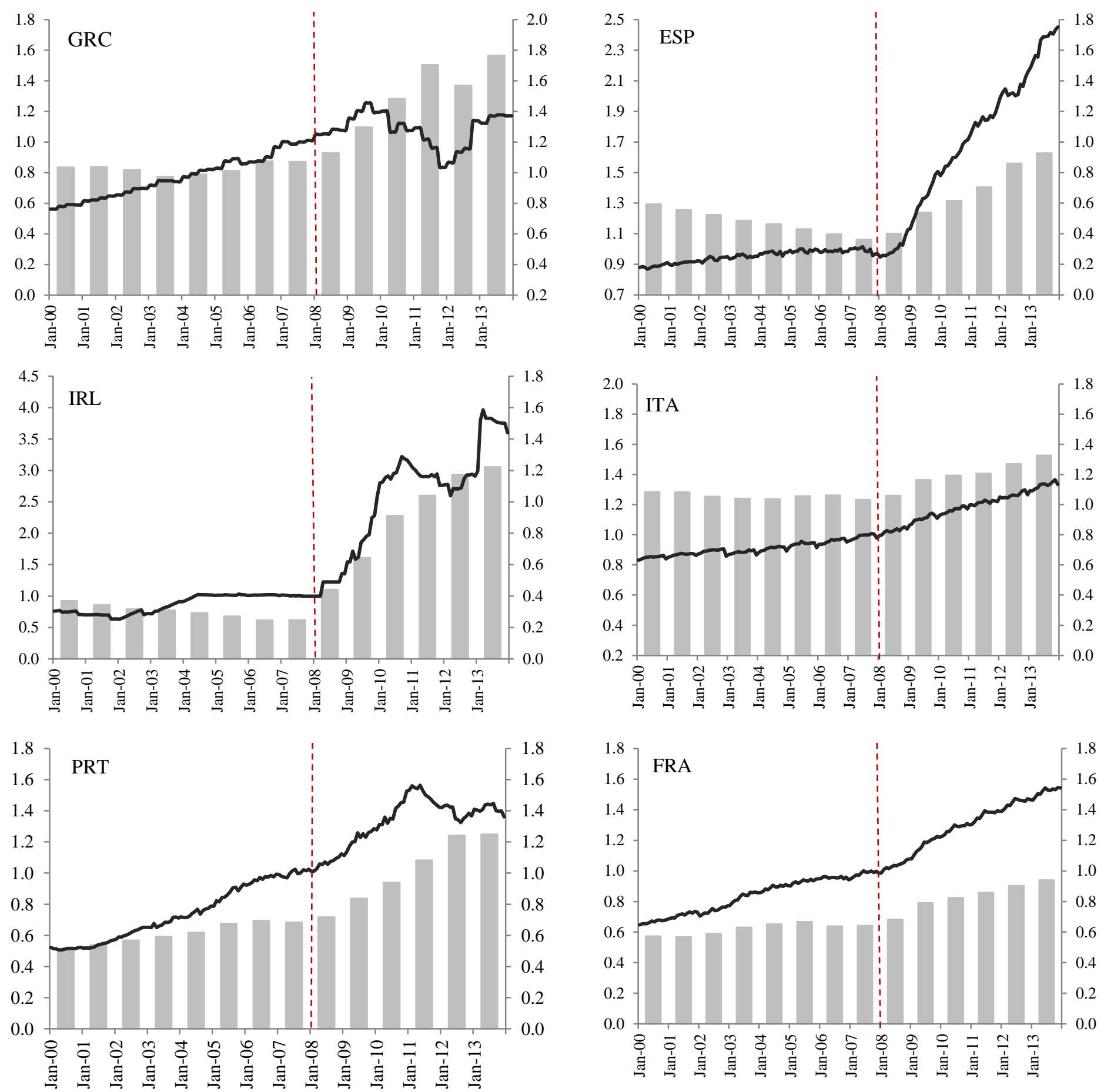

Notes: The figure plots Public debt /GDP ratio (bars) and public debt outstanding (line). For public debt we use general government gross debt according to the convergence criteria set out in the Maastricht Treaty, which comprises currency, bills and short-term bonds, other short-term loans, and other medium- and long- term loans and bonds, defined according to ESA 95 and available through https://stats.oecd.org/. Public debt outstanding (central government) is from ECB statistics. Public debt outstanding is normalized, with 2007:Q3 level equal to 1 . 


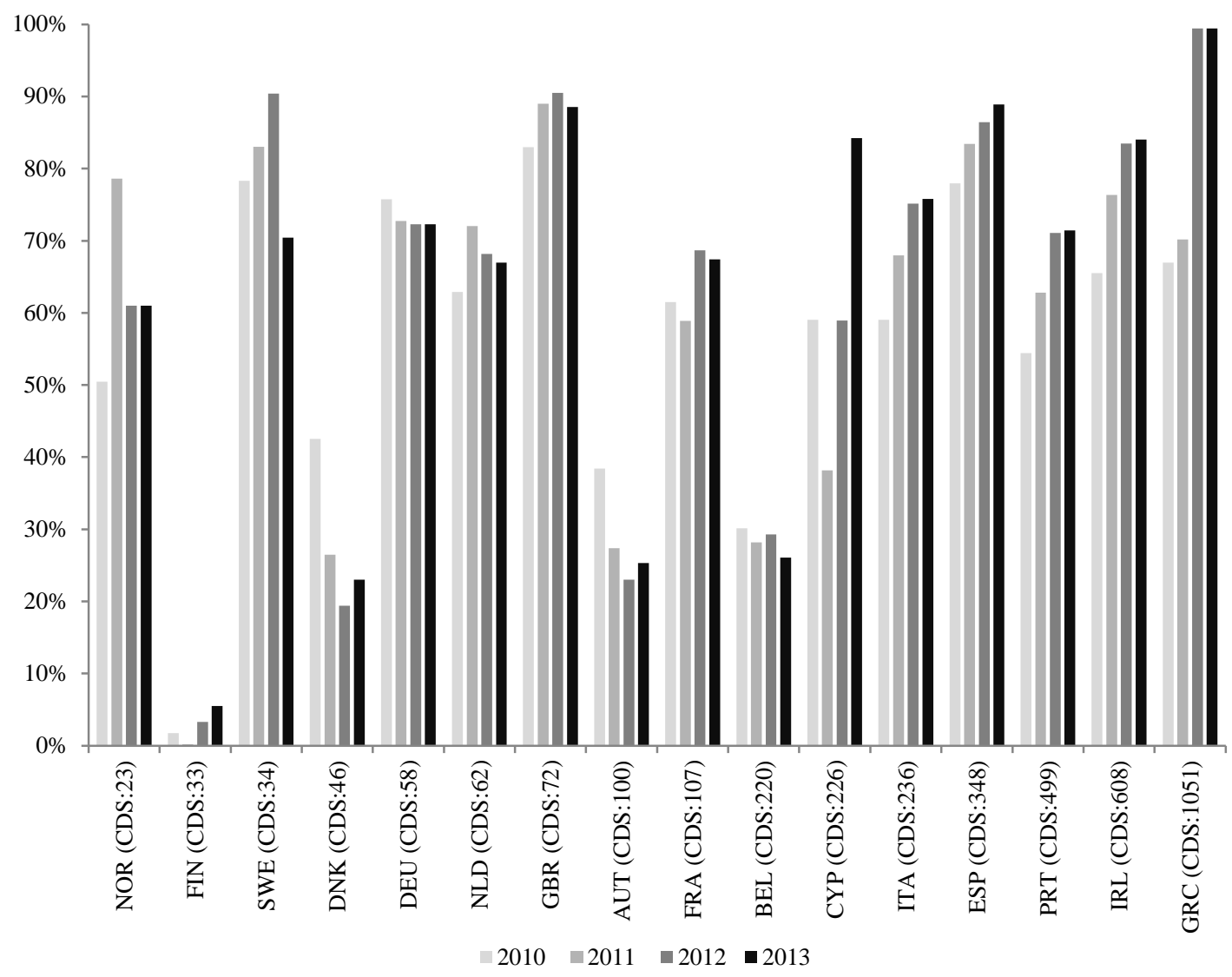

Notes: The figure is compiled from the European Central Bank, 2013 Transparency Exercise Summary Report. Countries are ranked based on CDS spreads measured in basis points as of December 2010. 
FIGURE 3. EUROZONE CORPORATE CREDIT SUPPLY

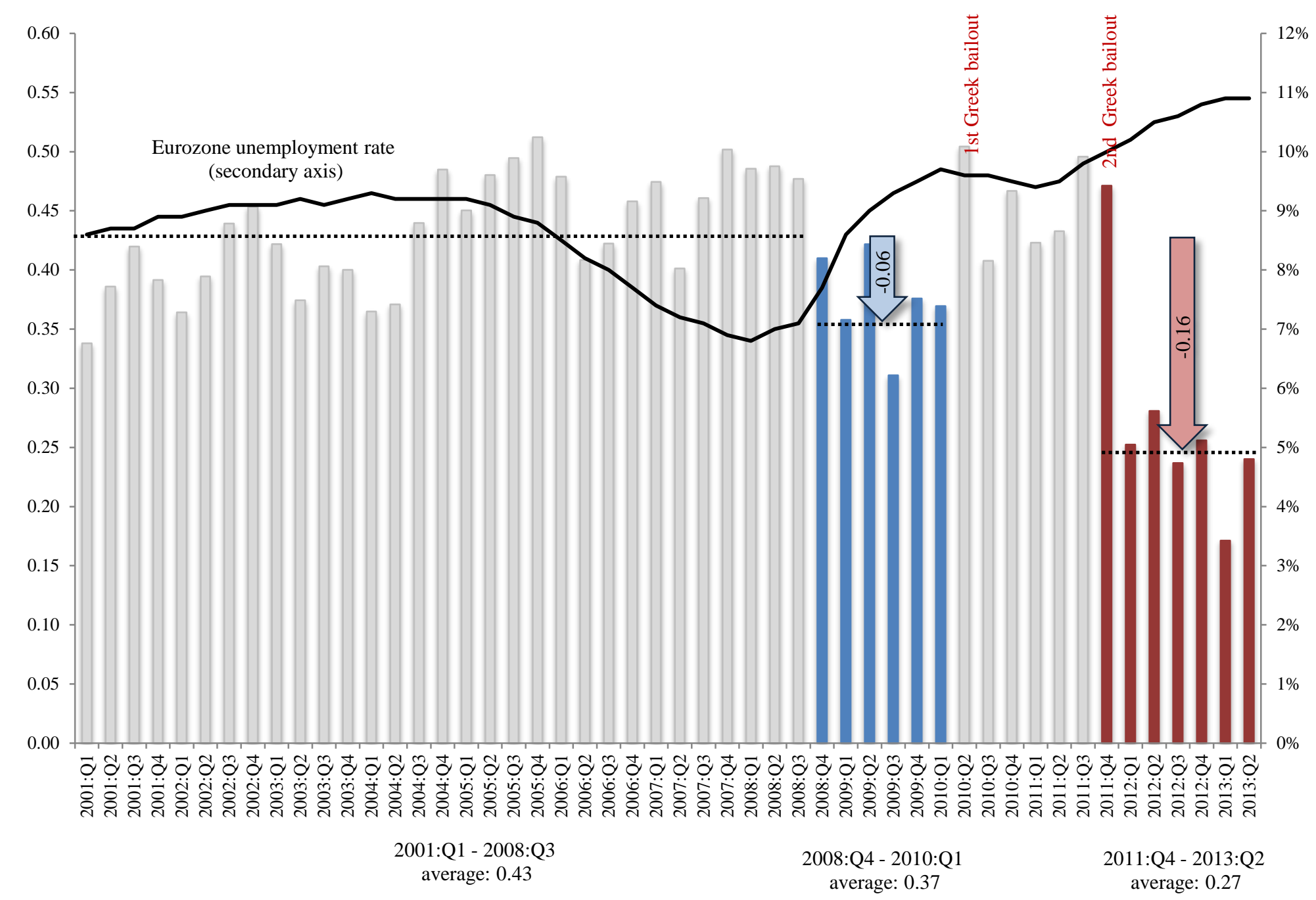

Notes: The figure shows the number of firms issuing new bank loans as a fraction of all firms issuing new debt in a given quarter (Bank debt/Total debt). Data on Eurozone unemployment rate is from Eurostat. 


\section{A. Corporate Bonds Yield Spread}

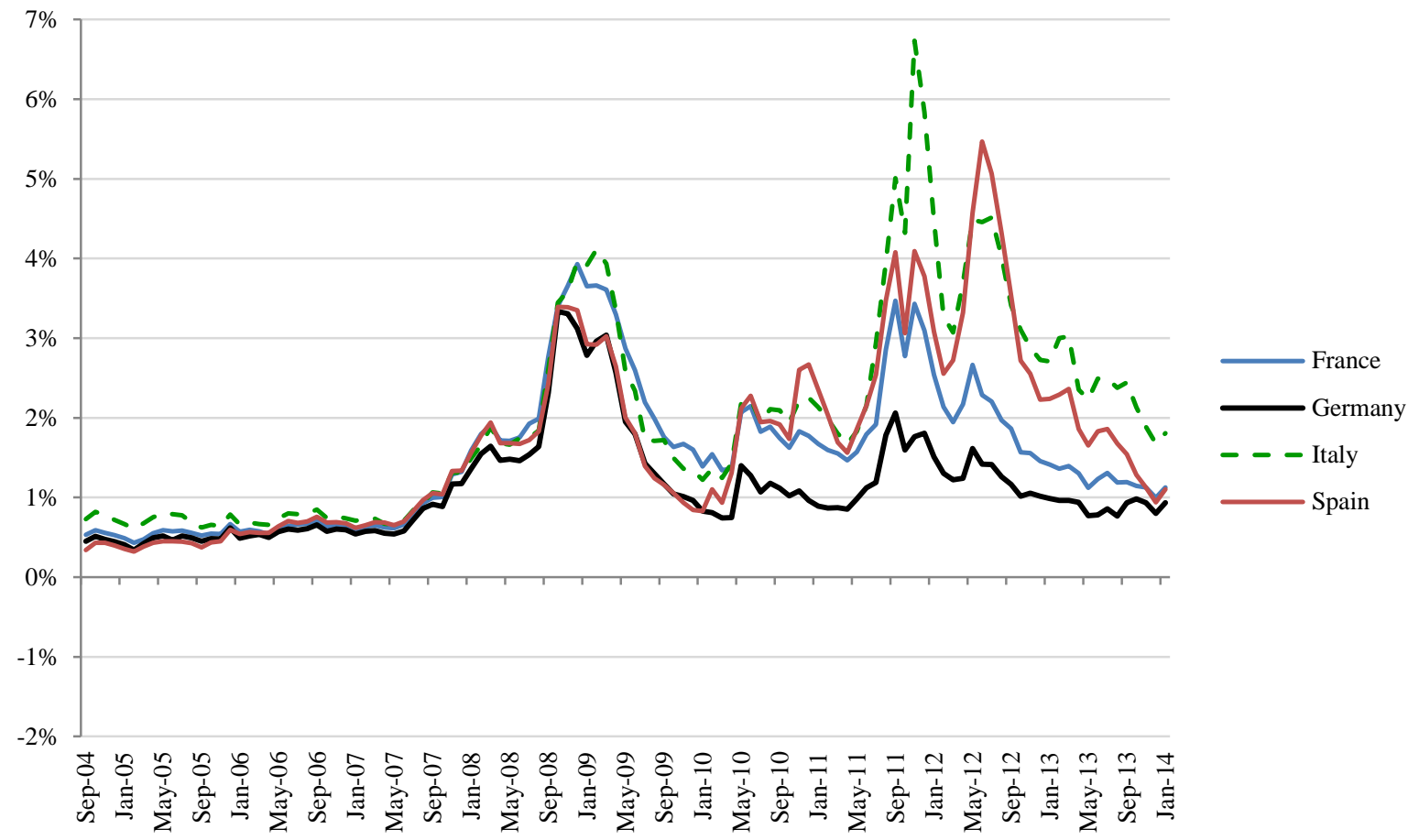

B. (Loan Rate - Corporate Bond Yield)

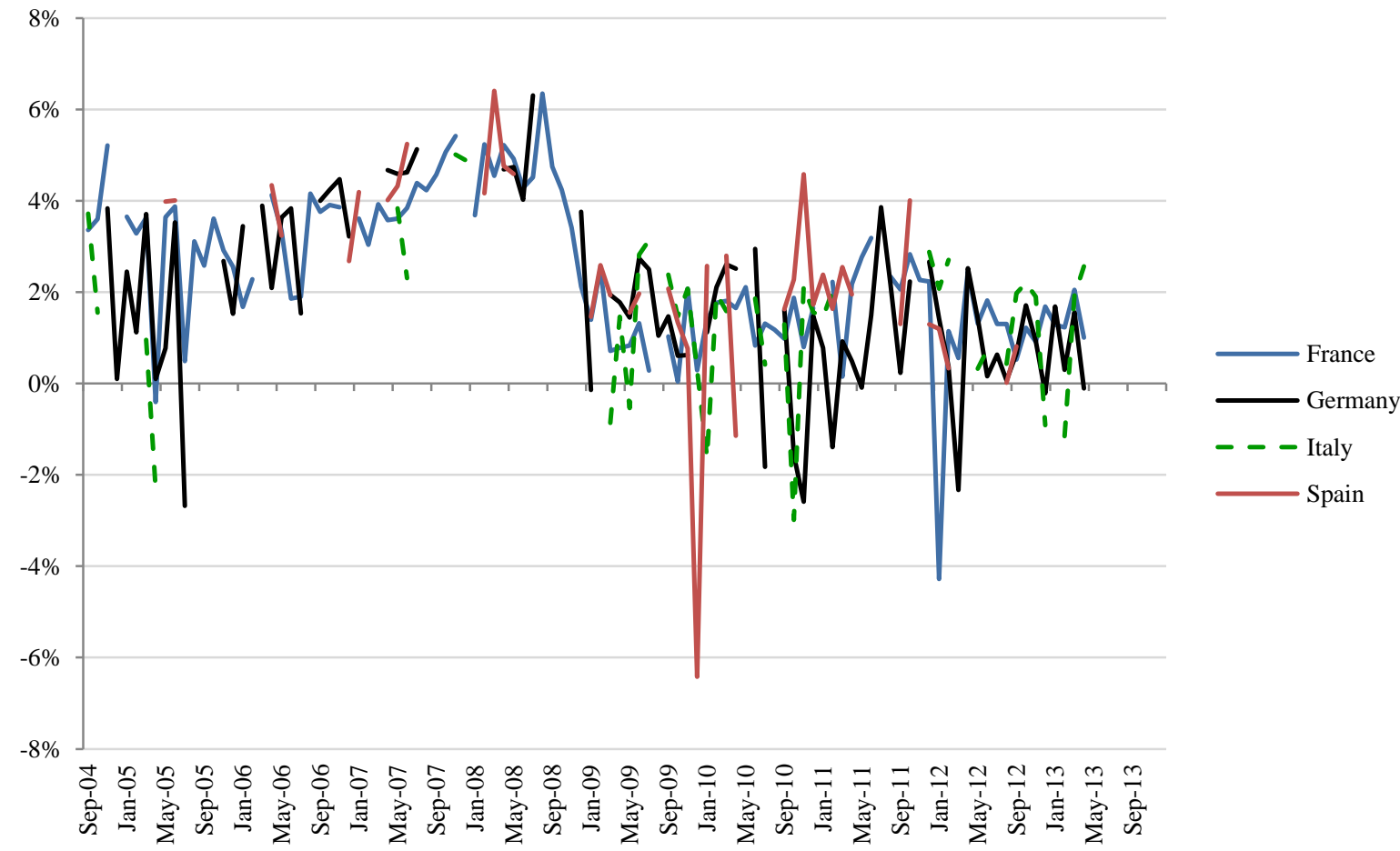

Notes: Panel A plots corporate yield spread over 5-year ECB yield curve spot rate; corporate bond yield corresponds to Barclays Aggregate Corporate yield as reported by Morningstar Direct. Panel B looks at the difference between yields on new loan and bonds issues. Bond yields are from SDC Platinum. Loan rates are rate on large new loans ("loans over 1 million euro at floating rate and up to 1 year initial rate fixation") reported by ECB. Loans are typically placed at par and are priced as a fixed spread over an interbank overnight rate (i.e., variable rate). To make yields across loans and bonds comparable, we adjust bond yield by the rate on the EURIBOR swap matched by maturity. Swap data is from Datastream. 


\section{FIGURE 5. THE ROLE OF GOVERNMENT-OWNED BANKS}

\section{A. World Bank Global Financial Development Report}

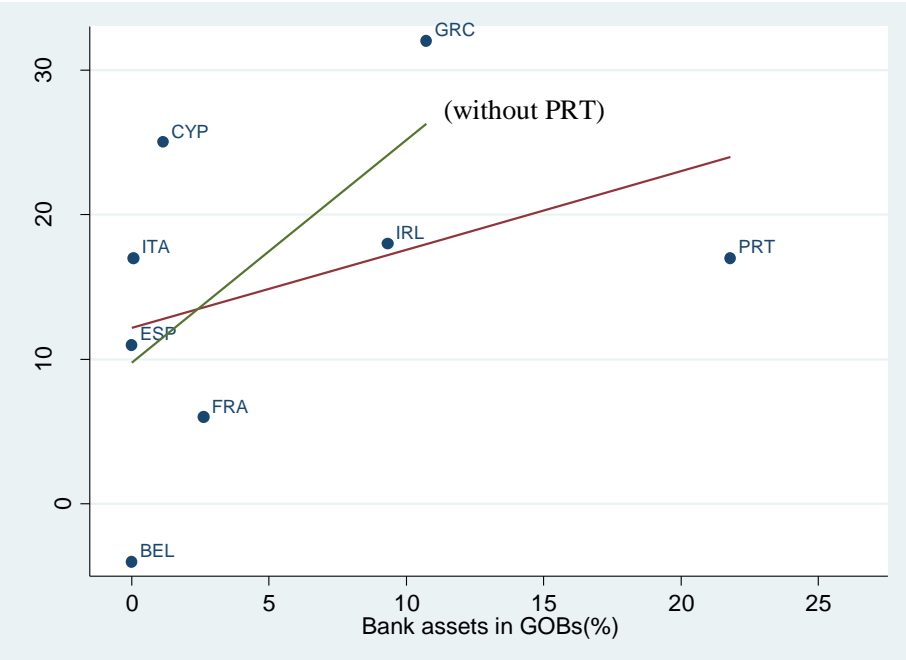

B. Bankscope, 2000-2009

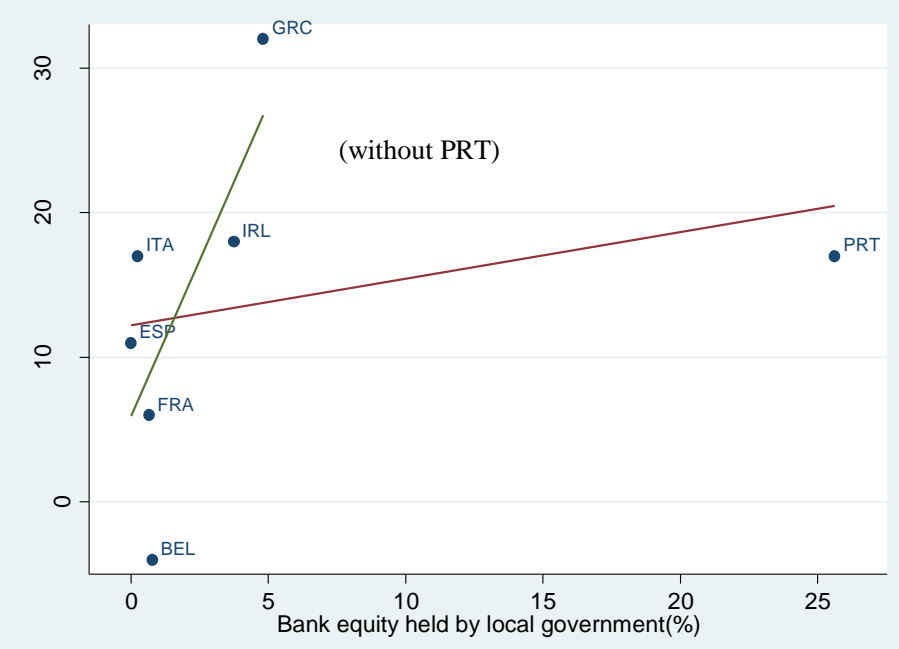

Notes: The figure plots change in domestic banks' share of bank-held sovereign bonds from 2010 to 2013 (vertical axis) against: (A) percent of the banking system's assets that is in government-controlled banks, i.e., where the government owned 50\% or more equity; and (B) percent of the large banks equity held by the local government. The first measure of government ownership of banks is compiled from the World Bank Global Financial Development Report 2013. It is based on the survey data, and corresponds to the average for the period from 2008-2010. The second measure is from Iannotta, Nocera, and Sironi (2013), who collected bank ownership information from 2000-2009 from Bankscope. The sample is constrained to European countries with CDS spread above 100 basis point as of December 2010. 
FIGURE 6. THE ROLE OF GOVERNMENT INFLUENCE ON THE BOARD OF DIRECTORS

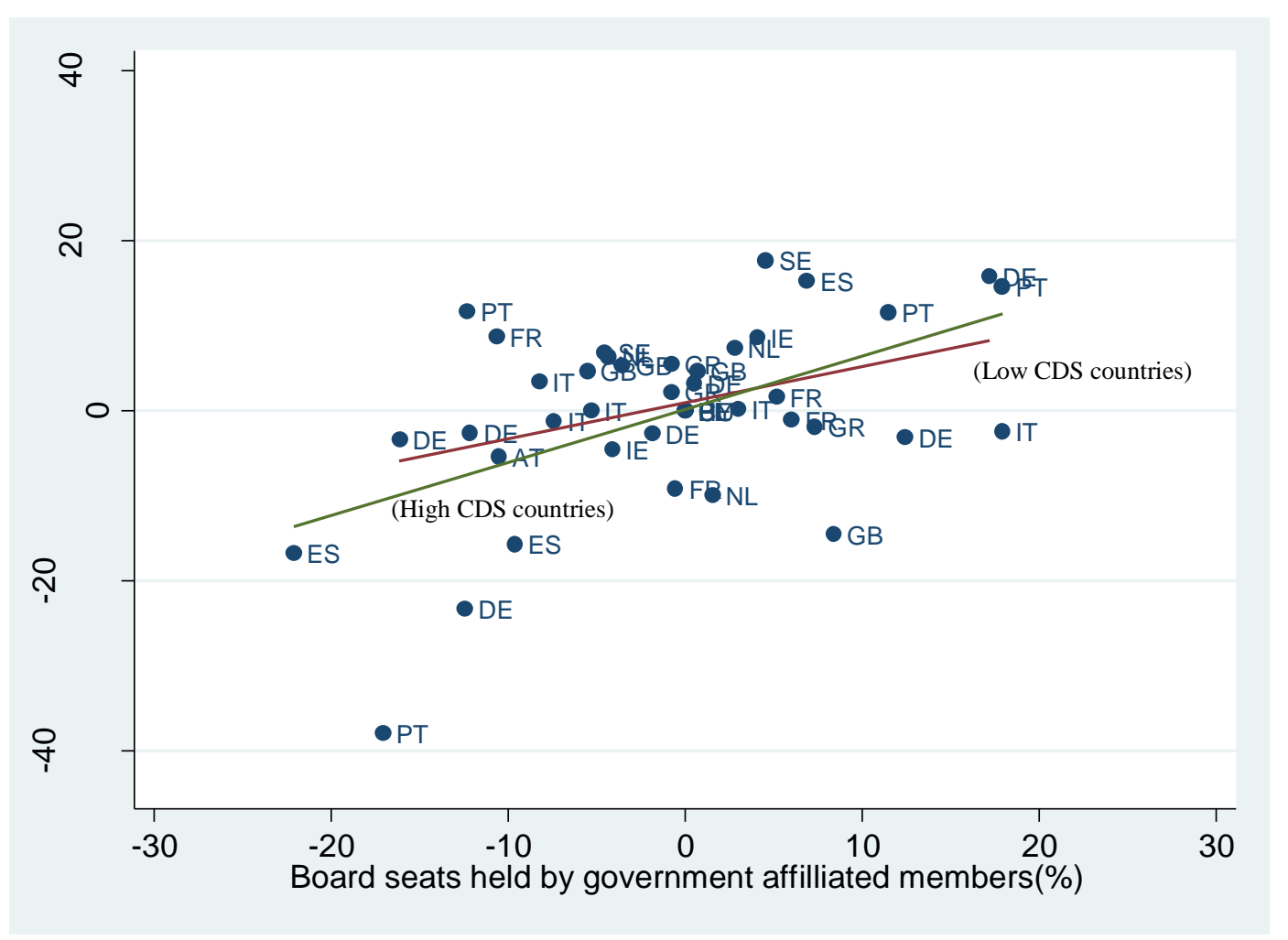

Notes: The figure plots change in domestic banks' share of bank-held sovereign bonds from 2011 to 2013 (vertical axis) against board seats held by government-affiliated persons. Each observation corresponds to one bank. Both variables are demeaned within countries. Data on boards of directors was compiled from BoardEx. Two separate regression lines are plotted: for countries with CDS spread above and below 100 basis points as of December 2010, respectively. The high CDS spread regression line, in green, has an $R$-squared of $29 \%$ (the slope is significant at the $1 \%$ level). The low CDS spread line has an $R$-squared of $13 \%$ (the slope is not statistically significant). 
TABLE 1 -SAMPLE DistRIBUTION OF LOAN VS. BOND CHOICE

\begin{tabular}{lccccc}
\hline \hline Country & & $\begin{array}{c}\text { Part of EBA } \\
\text { stress testing }\end{array}$ & $\begin{array}{c}\text { Loan officers } \\
\text { survey data start }\end{array}$ & $\begin{array}{c}\text { Bank share } \\
\text { (mean) }\end{array}$ & Obs. \\
\hline European Union (Eurozone): & AUT & Yes & -- & 0.384 & 58,016 \\
Austria & BEL & Yes & $2010: \mathrm{Q} 4$ & 0.448 & 101 \\
Belgium & FIN & Yes & -- & 0.384 & 216 \\
Finland & FRA & Yes & $2008: \mathrm{Q} 1$ & 0.348 & 1593 \\
France & DEU & Yes & $2003: \mathrm{Q} 1$ & 0.418 & 1211 \\
Germany & GRC & Yes & -- & 0.440 & 100 \\
Greece & ITA & Yes & $2003: \mathrm{Q} 1$ & 0.299 & 594 \\
Italy & LUX & Yes & $2003: \mathrm{Q} 1$ & 0.096 & 52 \\
Luxembourg & NLD & Yes & $2003: \mathrm{Q} 1$ & 0.328 & 547 \\
Netherlands & PRT & Yes & $2003: \mathrm{Q} 1$ & 0.436 & 78 \\
Portugal & ESP & Yes & $2003: \mathrm{Q} 1$ & 0.378 & 466 \\
Spain & & & & & 2,988 \\
European Union (other): & DNK & Yes & -- & 0.330 & 65 \\
Denmark & HUN & Yes & -- & 0.291 & 29 \\
Hungary & POL & Yes & -- & 0.714 & 14 \\
Poland & SWE & Yes & -- & 0.322 & 483 \\
Sweden & GBR & Yes & -- & 0.418 & 2397 \\
U.K. & & & -- & & 473 \\
Europe (other): & NOR & Yes & -- & 0.170 & 262 \\
Norway & CHE & -- & -- & 0.370 & 211 \\
Switzerland & & & & 0.373 & 8,477 \\
\hline Total & & & &
\end{tabular}

\begin{tabular}{lrr}
\hline Year & $\begin{array}{r}\text { Bank share } \\
\text { (mean) }\end{array}$ & Obs. \\
\hline 1996 & 0.254 & 271 \\
1997 & 0.264 & 260 \\
1998 & 0.292 & 304 \\
1999 & 0.285 & 419 \\
2000 & 0.272 & 454 \\
2001 & 0.341 & 506 \\
2002 & 0.411 & 491 \\
2003 & 0.413 & 553 \\
2004 & 0.437 & 574 \\
2005 & 0.505 & 603 \\
2006 & 0.392 & 572 \\
2007 & 0.438 & 511 \\
2008 & 0.426 & 419 \\
2009 & 0.331 & 542 \\
2010 & 0.427 & 557 \\
2011 & 0.481 & 583 \\
2012 & 0.240 & 587 \\
2013 & 0.247 & 271 \\
\hline Total & 0.373 & 8,477 \\
\hline
\end{tabular}

Notes: These tables present distribution of our core dependent variable $L_{i t}=1$ if a firm $i$ receives a loan and $L_{i t}=0$ if a firm issues a bond in quarter $t$. If in a given quarter a firm did not have a new loan or bond issue, it is not included in the sample. 
TABLE 2-WITHIN-FIRM EVIDENCE ON LOAN VS. BOND CHOICE

\begin{tabular}{|c|c|c|c|c|c|c|}
\hline & (1) & (2) & (3) & (4) & $(5)$ & (6) \\
\hline Tightening in lending standards & $\begin{array}{l}-0.094 * * \\
(0.034)\end{array}$ & -- & -- & -- & -- & -- \\
\hline Aggregate lending growth & -- & $\begin{array}{l}0.281 * * * \\
(0.098)\end{array}$ & -- & -- & -- & -- \\
\hline Non-performing loans & -- & -- & $\begin{array}{l}-7.834 * * * \\
(1.288)\end{array}$ & -- & -- & -- \\
\hline Loan allowances & -- & -- & -- & $\begin{array}{l}-27.823 * * * \\
(6.997)\end{array}$ & -- & -- \\
\hline GDP growth & -- & -- & -- & -- & $\begin{array}{l}1.018 * * * \\
(0.282)\end{array}$ & -- \\
\hline Bank stock-index & -- & -- & -- & -- & -- & $\begin{array}{l}3.941^{*} \\
(0.244)\end{array}$ \\
\hline $\begin{array}{l}\text { Fixed effects } \\
\text { Firm }\left(c_{i}\right)\end{array}$ & Yes & Yes & Yes & Yes & Yes & Yes \\
\hline $\begin{array}{l}\text { Obs. } \\
R \text {-squared } \\
\text { Clusters (It) }\end{array}$ & $\begin{array}{l}3,197 \\
0.43 \\
80\end{array}$ & $\begin{array}{l}7,036 \\
0.39 \\
249\end{array}$ & $\begin{array}{l}8,206 \\
0.37 \\
284\end{array}$ & $\begin{array}{l}8,206 \\
0.36 \\
284\end{array}$ & $\begin{array}{l}8,451 \\
0.39 \\
294\end{array}$ & $\begin{array}{l}8,331 \\
0.36 \\
297\end{array}$ \\
\hline Mean $\left(L_{i t}\right)$ & 0.397 & 0.380 & 0.377 & 0.377 & 0.373 & 0.374 \\
\hline
\end{tabular}

Notes: The dependent variable is $L_{i t}=1$ if a firm $i$ receives a loan and $L_{i t}=0$ if a firm issues a bond in quarter $t$. If in a given quarter a firm did not have a new loan or bond issue, it is not included in the sample. The table reports the results of our linear regressions. Specifications (1) though (3):

$$
L_{i t}=c_{i}+\beta S_{I t},
$$

where $c_{i}$ is firm fixed effects and $S_{I t}$ is a quarterly country-level measure of macroeconomic conditions. Data on tightening in lending standards comes from ECB and corresponds to the net percentage of banks tightening credit standard for new loans or credit lines to enterprises. Country-level measures of Aggregate lending growth, Non-performing, and Loan allowances are compiled from Bankscope. Lending growth is measured as a four-quarter rolling-window growth in aggregate loans outstanding. Non-performing loans and loan allowances are scaled by total loans, and correspond to the assets-weighted average for the banks within a given country. GDP growth is real change in per capita GDP, determined quarterly (measured with respect to the same quarter the year prior to avoid seasonality); the data is collected from the Eurostat website. Bank stock-index is a logarithm of an equally weighted stock index. Errors are heteroskedasticity-robust and clustered by country*year.

*** Significant at the 1 percent level.

** Significant at the 5 percent level.

* Significant at the 10 percent level. 
TABle 3-BANKS’ BALANCE SHEETS AND BANK CREDit SUPPLY

\begin{tabular}{|c|c|c|c|c|c|c|c|c|}
\hline \multirow{2}{*}{$\begin{array}{l}\text { Source of banks' sovereign debt holdings: } \\
\text { Sample: }\end{array}$} & \multicolumn{3}{|c|}{ EBA } & \multicolumn{2}{|c|}{ Bruegel } & \multicolumn{3}{|c|}{ Bankscope } \\
\hline & $\begin{array}{l}2010-2013 \\
\text { (1) }\end{array}$ & $\begin{array}{l}2010-2013 \\
(2)\end{array}$ & $\begin{array}{l}2010-2013 \\
\text { (3) }\end{array}$ & $\begin{array}{l}1999-2013 \\
\text { (4) }\end{array}$ & $\begin{array}{l}1999-2013 \\
(5)\end{array}$ & $\begin{array}{l}1997-2013 \\
(6)\end{array}$ & $\begin{array}{l}2007-2013 \\
(7)\end{array}$ & $\begin{array}{l}2007-2013 \\
(8)\end{array}$ \\
\hline \multicolumn{9}{|l|}{ Domestic sovereign debt held by banks: } \\
\hline (\% of RWA) & $\begin{array}{l}-0.971 * * * \\
(0.150)\end{array}$ & -- & -- & -- & -- & -- & -- & -- \\
\hline$(\%$ of RWA $) *$ Country CDS spread & -- & $\begin{array}{l}-0.202 * * * \\
(0.049)\end{array}$ & -- & -- & -- & -- & -- & -- \\
\hline (\% of common equity) $*$ Country CDS spread & -- & -- & $\begin{array}{l}-0.089 * \\
(0.487)\end{array}$ & -- & -- & -- & -- & -- \\
\hline (\% of bank assets) & -- & -- & -- & $\begin{array}{l}-0.564 * * * \\
(0.175)\end{array}$ & -- & -- & -- & -- \\
\hline (\% of bank assets) $*$ Country CDS spread & -- & -- & -- & -- & $\begin{array}{l}-0.042 * * \\
(0.019)\end{array}$ & -- & -- & -- \\
\hline \multicolumn{9}{|l|}{ All sovereign debt held by banks } \\
\hline (\% bank assets) & -- & -- & -- & -- & -- & $\begin{array}{l}-1.347^{*} \\
(0.815)\end{array}$ & $\begin{array}{l}-11.210 \text { **** } \\
(2.041)\end{array}$ & -- \\
\hline (\% of bank assets) $*$ Country CDS spread & -- & -- & -- & -- & -- & -- & -- & $\begin{array}{l}-0.141 * * * \\
(0.050)\end{array}$ \\
\hline \multicolumn{9}{|l|}{ Fixed effects } \\
\hline Firm $\left(c_{i}\right)$ & Yes & Yes & Yes & Yes & Yes & Yes & Yes & Yes \\
\hline Obs. & 1,923 & 1,646 & 1,646 & 7,421 & 4,641 & 7,935 & 3,926 & 2,896 \\
\hline$R$-squared & 0.59 & 0.60 & 0.62 & 0.38 & 0.44 & 0.37 & 0.54 & 0.54 \\
\hline Clusters & 65 & 57 & 57 & 246 & 157 & 269 & 104 & 91 \\
\hline Mean $\left(L_{i t}\right)$ & 0.376 & 0.389 & 0.389 & 0.392 & 0.411 & 0.403 & 0.408 & 0.397 \\
\hline
\end{tabular}

Notes: The dependent variable is $L_{i t}=1$ if a firm $i$ receives a loan and $L_{i t}=0$ if a firm issues a bond in quarter $t$. If in a given quarter a firm did not have a new loan or bond issue, it is not included in the sample. Specifications (1), (4) and (5) correspond to:

$\qquad L_{i t}=c_{i}+\beta B_{I T}$

where $c_{i}$ is firm fixed effects and $B_{I T}$ is domestic bank-sector holding of sovereign debt measured on semiannual or annual frequency. Specification (6) also includes year fixed effects $D_{T}$. Specifications (2) and (3) correspond to:

CDS data $L_{i t}=c_{i}+\beta B_{I T} * C D S_{I T-1}$

elered by country*year.

*** Significant at the 1 percent level.

** Significant at the 5 percent level.

* Significant at the 10 percent level. 
TABLE 4-FIRM TIME-VARYING CHARACTERISTICS, 2010-2013

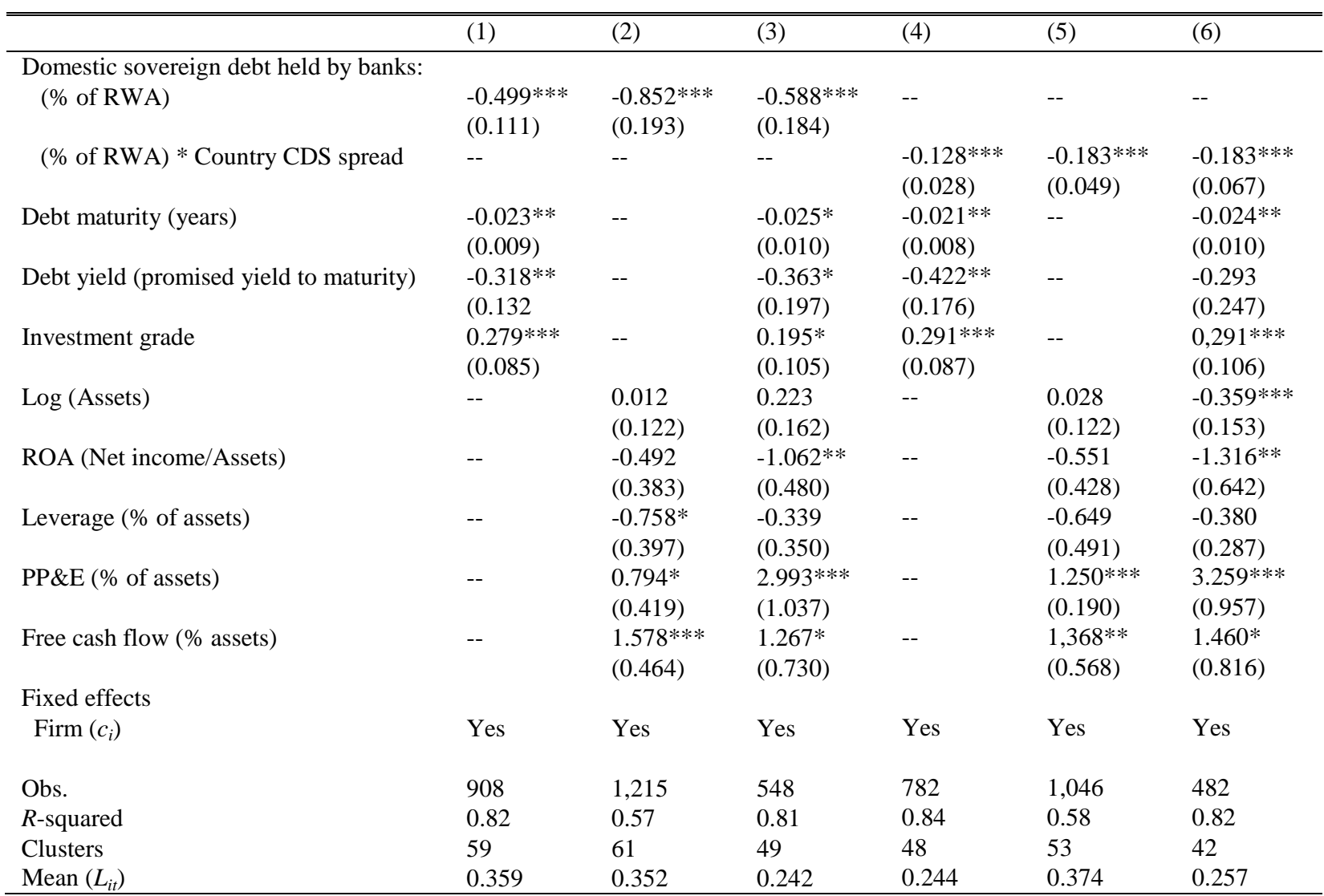

Notes: Results reported here expand on specifications (1) and (2) in Table 3 by including time-varying firm characteristics. Errors are heteroskedasticity-robust and clustered by country*year.

$* * *$ Significant at the 1 percent level.

** Significant at the 5 percent level.

* Significant at the 10 percent level. 
TABle 5-RELATIONSHIP BANKS’ BALANCE SHEETS AND BANK CREDit SuPPLy, 2010-2013

\begin{tabular}{|c|c|c|c|c|}
\hline Sample: & (1) & (2) & (3) & (4) \\
\hline \multicolumn{5}{|l|}{ Domestic sovereign debt held by banks: } \\
\hline (\% of RWA) & $\begin{array}{l}-0.584 * * * \\
(0.120)\end{array}$ & -- & -- & $\begin{array}{l}-0.901 * * \\
(0.415)\end{array}$ \\
\hline$(\%$ of RWA $) *$ Country CDS spread & -- & $\begin{array}{l}-0.263 * * \\
(0.130)\end{array}$ & -- & -- \\
\hline (\% of common equity) $*$ Country CDS spread & -- & -- & $\begin{array}{l}-0.035 \\
(0.034)\end{array}$ & -- \\
\hline \multicolumn{5}{|l|}{ Fixed effects } \\
\hline $\operatorname{Bank}\left(D_{j}\right)$ & Yes & Yes & Yes & Yes \\
\hline Year-quarter $\left(D_{t}\right)$ & Yes & Yes & Yes & Yes \\
\hline Obs. & 4,251 & 4,195 & 4,185 & 2,148 \\
\hline$R$-squared & 0.16 & 0.16 & 0.16 & 0.18 \\
\hline Mean $\left(L_{i t}\right)$ & -0.09 & -0.09 & -0.09 & -0.07 \\
\hline
\end{tabular}

Notes: The analysis in this table focuses on matching between specific banks and firms. The dependent variable is the residual from the firm fixed effect regression of $L_{i t}=1$ if a firm $i$ receives a loan and $L_{i t}=0$, estimated for the full sample period 1996-2013. The results reported in this table relate the estimated residual to the firm's relationship bank's holdings of domestic sovereign debt; the period of the analysis is 2010-2013. A relationship between a firm and a bank is taken to exist if a bank was a lead or co-lead in a syndicated loan taken out in the last five years. As before, a firm appears in the sample (i.e., the residual is computed) if in a given period it loan or a bond. Specification (1) corresponds to:

$$
\widehat{L}_{i t}=D_{t}+D_{j \mid(i, t)}+\beta B_{j \mid(i, t) t} \text {, }
$$

where $\hat{L}_{i t}$ is the residual after firm fixed effects $\left(c_{i}\right), D_{t}$ is year-quarter fixed effects, $D_{j(i, t)}$ is bank fixed effects for the bank $j$ for which firm $i$ had a relationship at time $t$, and $B_{j t}$ is the relationship bank's holdings of its home country's sovereign debt. Specifications (2) and (3) correspond to:

$$
\widehat{L}_{i t}=D_{t}+D_{j(i, t)}+\beta \log \left(B_{i t} * C D S_{c(j) t}\right),
$$

where $C D S_{c(j) t}$ is the sovereign CDS spread of the bank's home country. Specification (4) only includes firms with a unique relationship bank. Local sovereign debt holdings are from EBA. Total sovereign debt holdings are from Bankscope. CDS data is from Markit. Errors are heteroskedasticity-robust and clustered by country*year. Outliers for exposure * CDS (top and bottom $1 \%$ ) have been excluded.

*** Significant at the 1 percent level.

** Significant at the 5 percent level.

* Significant at the 10 percent level. 
TABLE 6-FINANCIAL REPRESSION VS. RISK-SHIFTING

Panel A. Domestic vs. riskiest sovereign debt holdings

\begin{tabular}{|c|c|c|c|c|}
\hline Bank holdings, 2010-2013: & (1) & (2) & (3) & (4) \\
\hline Domestic sovereign debt & $\begin{array}{l}-0.918^{* *} \\
(0.363)\end{array}$ & -- & $\begin{array}{l}-0.890 * * * \\
(0.263)\end{array}$ & -- \\
\hline Greek sovereign debt & $\begin{array}{l}2.416 \\
(34.306)\end{array}$ & -- & -- & -- \\
\hline Sovereign debt of 3 riskiest EURO-area countries (except domestic) & -- & -- & $\begin{array}{l}-0.444 * \\
(0.254)\end{array}$ & -- \\
\hline Domestic sovereign debt $*$ Country CDS spread & -- & $\begin{array}{l}-0.131 * * \\
(0.059)\end{array}$ & -- & $\begin{array}{l}-0.223 * * * \\
(0.069)\end{array}$ \\
\hline Greek sovereign debt $*$ German CDS spread & -- & $\begin{array}{l}4.952 * * \\
(7.760)\end{array}$ & -- & -- \\
\hline Sovereign debt of 3 riskiest EURO-area countries * Country CDS spread & -- & -- & -- & $\begin{array}{l}0.326 \\
(0.418)\end{array}$ \\
\hline \multicolumn{5}{|l|}{ Fixed effects } \\
\hline Firm $\left(c_{i}\right)$ & Yes & Yes & Yes & Yes \\
\hline Obs. & 1,784 & 1,477 & 1,804 & 1,477 \\
\hline$R$-squared & 0.68 & 0.70 & 0.68 & 0.69 \\
\hline Mean $\left(L_{i t}\right)$ & 0.349 & 0.346 & 0.349 & 0.346 \\
\hline
\end{tabular}

Panel B. Bank risk

\begin{tabular}{|c|c|c|c|c|c|c|}
\hline & \multirow[b]{3}{*}{ Obs. } & \multicolumn{5}{|c|}{ Domestic sovereign debt } \\
\hline & & \multicolumn{3}{|c|}{$\%$ of RWA } & \multicolumn{2}{|c|}{ Growth } \\
\hline & & 2011 & 2012 & 2013 & $2011-12$ & $2011-13$ \\
\hline \multicolumn{7}{|l|}{ Full sample: } \\
\hline Total capital (\% of RWA), lagged & 64 & $0.603 * * *$ & 0.159 & $0.216^{*}$ & -0.124 & -0.371 \\
\hline Core tier 1 capital ratio $(\%), 2010$ & 63 & $0.502 * * *$ & $0.377 * * *$ & $0.286^{* *}$ & $-0.240 *$ & $-0.308 * *$ \\
\hline Core tier 1 capital ratio (\%), 2011E, baseline scenario & 63 & $0.332 * *$ & $0.246^{*}$ & 0.167 & $-0.241 *$ & $-0.304 * *$ \\
\hline Core tier 1 capital ratio $(\%), 2011 \mathrm{E}$, adverse scenario & 63 & 0.180 & 0.110 & 0.048 & -0.208 & -0.244 \\
\hline Tier 1 Capital (\% RWA), 2010 & 63 & $0.502 * * *$ & $0.388 * * *$ & $0.313 * *$ & $-0.237 *$ & $-0.267 * *$ \\
\hline CDS (lagged), senior secured debt & 33 & -0.025 & -0.033 & -0.135 & 0.158 & 0.216 \\
\hline CDS (lagged), senior unsecure debt & 29 & 0.151 & 0.033 & 0.014 & 0.105 & 0.173 \\
\hline \multicolumn{7}{|l|}{ Country CDS spread $>100$ bps as of December 2010: } \\
\hline Total capital (\% of RWA), lagged & 32 & $0.414 * *$ & 0.062 & 0.110 & -0.032 & $-0.394 * *$ \\
\hline Core tier 1 capital ratio (\%), 2010 & 32 & 0.306 & 0.025 & -0.114 & -0.203 & -0.245 \\
\hline Core tier 1 capital ratio (\%), 2011E, baseline scenario & 32 & $0.330 *$ & 0.050 & -0.061 & -0.205 & -0.204 \\
\hline Core tier 1 capital ratio $(\%), 2011 \mathrm{E}$, adverse scenario & 32 & $0.316^{*}$ & 0.048 & -0.025 & -0.190 & -0.145 \\
\hline Tier 1 Capital (\% RWA), 2010 & 32 & 0.156 & 0.008 & -0.085 & -0.178 & -0.086 \\
\hline CDS (lagged), senior secured debt & 16 & -0.051 & -0.260 & -0.388 & -0.105 & -0.109 \\
\hline CDS (lagged), senior unsecure debt & 13 & -0.046 & -0.171 & -0.119 & -0.068 & -0.028 \\
\hline
\end{tabular}

Notes: Panel A looks separately at the effect of local vs. riskiest sovereign debt holdings. Specifications (1) and (2) in Panel A are similar to specifications (1) and (2) in Table 3 but add holdings of Greek debt (Greek firms are excluded). In columns (3) and (4), instead of Greek debt, we measure the holdings by a country's banks of sovereign debt from the three highest CDS spread countries except the domestic sovereign. Sovereign CDS spreads are measured at end of preceding year. Standard errors are heteroskedasticity-robust and clustered by country*year. In Panel B, we look at cross-sectional correlation between bank health and local sovereign bonds holdings. Capital adequacy measures are from ECB. CDS rates are from Markit. Unless otherwise indicated, bank risk is measured as of the end of the previous year. CDS Spreads correspond to the last quarter average.

*** Significant at the 1 percent level.

** Significant at the 5 percent level.

* Significant at the 10 percent level. 
TABLE 7-FinANCIAL REPRESSION VS. LIQUIDITY SHOCK

Panel A. Domestic vs. safest sovereign debt holdings

\begin{tabular}{|c|c|c|c|c|}
\hline Bank holdings, 2010-2013: & (1) & (2) & (3) & (4) \\
\hline Domestic sovereign debt & $\begin{array}{l}-1.419 * * * \\
(0.309)\end{array}$ & -- & $\begin{array}{l}-0.986 \text { *** } \\
(0.264)\end{array}$ & -- \\
\hline German sovereign debt & $\begin{array}{l}0.704^{*} \\
(0.359)\end{array}$ & -- & -- & -- \\
\hline Sovereign debt of 3 safest EURO-area countries (except domestic) plus Germany & -- & -- & $\begin{array}{l}-0.068 \\
(0.451)\end{array}$ & -- \\
\hline Domestic sovereign debt $*$ Country CDS spread & -- & $\begin{array}{l}-0.177 * * * \\
(0.059)\end{array}$ & -- & $\begin{array}{l}-0.200 * * * \\
(0.065)\end{array}$ \\
\hline German sovereign debt $*$ German CDS spread & -- & $\begin{array}{l}-6.281 * * \\
(2.930)\end{array}$ & -- & -- \\
\hline Sovereign debt of 3 safest EURO-area countries plus Germany * Country CDS spread & -- & -- & -- & $\begin{array}{l}-3.031 \\
(2.922)\end{array}$ \\
\hline \multicolumn{5}{|l|}{ Fixed effects } \\
\hline Firm $\left(c_{i}\right)$ & Yes & Yes & Yes & Yes \\
\hline Obs. & 1,385 & 1,113 & 1,385 & 1,113 \\
\hline$R$-squared & 0.66 & 0.68 & 0.66 & 0.68 \\
\hline Mean $\left(L_{i t}\right)$ & 0.347 & 0.371 & 0.348 & 0.371 \\
\hline
\end{tabular}

Panel B. Evolution of domestic sovereign debt holdings outside of the banking sector

\begin{tabular}{|c|c|c|c|c|c|c|c|c|c|}
\hline Pension and insurance sector & Source & 2006 & 2007 & 2008 & 2009 & 2010 & 2011 & 2012 & 2013 \\
\hline \multicolumn{10}{|l|}{ Domestic sovereign debt (\% of all sovereign debt) } \\
\hline PRT: Insurance & Instituto de Seguros de Portugal (ISP) & $23 \%$ & $22 \%$ & $23 \%$ & $22 \%$ & $46 \%$ & $50 \%$ & $66 \%$ & -- \\
\hline PRT: Pensions & Instituto de Seguros de Portugal (ISP) & $20 \%$ & $19 \%$ & $14 \%$ & $18 \%$ & $30 \%$ & $32 \%$ & $29 \%$ & -- \\
\hline ESP: Social Security Reserve Fund (Pensions) & Ministerio de Empleo y Seguridad Social & $55 \%$ & $51 \%$ & $56 \%$ & $77 \%$ & $88 \%$ & $90 \%$ & $97 \%$ & $97 \%$ \\
\hline DEU: Allianz (Insurance) & www.allianz.com & $14 \%$ & $14 \%$ & $22 \%$ & $25 \%$ & $22 \%$ & $20 \%$ & $16 \%$ & $16 \%$ \\
\hline FRA: Public Service Additional Pension Scheme (Pensions) & www.rafp.fr & $55 \%$ & $41 \%$ & $32 \%$ & $30 \%$ & $41 \%$ & $43 \%$ & -- & -- \\
\hline \multicolumn{10}{|l|}{ Domestic sovereign debt (\% of assets) } \\
\hline PRT: Insurance & Instituto de Seguros de Portugal (ISP) & $6 \%$ & $5 \%$ & $6 \%$ & $5 \%$ & $13 \%$ & $16 \%$ & $25 \%$ & -- \\
\hline PRT: Pensions & Instituto de Seguros de Portugal (ISP) & $5 \%$ & $4 \%$ & $4 \%$ & $4 \%$ & $8 \%$ & $8 \%$ & $10 \%$ & -- \\
\hline ESP: Social Security Reserve Fund (Pensions) & Ministerio de Empleo y Seguridad Social & $55 \%$ & $51 \%$ & $56 \%$ & $77 \%$ & $88 \%$ & $90 \%$ & $97 \%$ & $97 \%$ \\
\hline DEU: Allianz (Insurance) & www.allianz.com & $1 \%$ & $1 \%$ & $3 \%$ & $5 \%$ & $5 \%$ & $5 \%$ & $4 \%$ & $4 \%$ \\
\hline FRA: Public Service Additional Pension Scheme (Pensions) & www.rafp.fr & $47 \%$ & $41 \%$ & $31 \%$ & $24 \%$ & $22 \%$ & $28 \%$ & $24 \%$ & - \\
\hline
\end{tabular}

Notes: Panel A is equivalent to Panel A in Table 6, but the emphasis here is on safest sovereign debt holdings. Sovereign CDS spreads are measured at end of preceding year. Standard errors are heteroskedasticity-robust and clustered by country*year. Panel B reports evolution of domestic sovereign holdings of pension funds and insurance companies. 
TABLE 8-Domestic SOVEREIGN DEBT AND BANK CREDIT SUPPLY

\begin{tabular}{|c|c|c|c|c|c|c|c|c|c|}
\hline Sample: & $\begin{array}{l}\text { 1996-2012 } \\
\text { (1) }\end{array}$ & $\begin{array}{l}1996-2006 \\
\text { (2) }\end{array}$ & $\begin{array}{l}2007-2012 \\
\text { (3) }\end{array}$ & $\begin{array}{l}1996-2012 \\
\text { (4) }\end{array}$ & $\begin{array}{l}1996-2006 \\
\text { (5) }\end{array}$ & $\begin{array}{l}2007-2012 \\
\text { (6) }\end{array}$ & $\begin{array}{l}1996-2012 \\
\text { (7) }\end{array}$ & $\begin{array}{l}1996-2006 \\
\text { (8) }\end{array}$ & $\begin{array}{l}2007-2012 \\
\text { (9) }\end{array}$ \\
\hline Domestic sovereign debt/ GDP & $\begin{array}{l}-0.208 * * \\
(0.105)\end{array}$ & $\begin{array}{l}-0.261^{*} \\
(0.139)\end{array}$ & $\begin{array}{l}-0.352 * * * \\
(0.096)\end{array}$ & -- & -- & -- & -- & -- & -- \\
\hline Domestic sovereign debt/GDP $*$ Country CDS spread & -- & -- & -- & $\begin{array}{l}-0.003^{* * *} \\
(0.001)\end{array}$ & $\begin{array}{l}0.349 \\
(0.922)\end{array}$ & $\begin{array}{l}-0.004 * * * \\
(0.001)\end{array}$ & -- & -- & -- \\
\hline Domestic sovereign debt $>60 \%$ GDP & -- & -- & -- & -- & -- & -- & $\begin{array}{l}-0.003 \\
(0.020)\end{array}$ & $\begin{array}{l}0.017 \\
(0.023)\end{array}$ & $\begin{array}{l}0.019 \\
(0.062)\end{array}$ \\
\hline Domestic sovereign debt $>90 \%$ GDP & -- & -- & -- & -- & -- & -- & $\begin{array}{l}-0.152 * * * \\
(0.037)\end{array}$ & $\begin{array}{l}0.124 * * \\
(0.057)\end{array}$ & $\begin{array}{l}-0.099 \\
(0.079)\end{array}$ \\
\hline Domestic sovereign debt $>120 \%$ GDP & -- & -- & -- & -- & -- & -- & $\begin{array}{l}-0.335^{* * * *} \\
(0.048)\end{array}$ & -- & $\begin{array}{l}-0.252 * * * \\
(0.087)\end{array}$ \\
\hline $\begin{array}{l}\text { Fixed effects } \\
\text { Firm }\left(c_{i}\right)\end{array}$ & Yes & Yes & Yes & Yes & Yes & Yes & Yes & Yes & Yes \\
\hline $\begin{array}{l}\text { Obs. } \\
R \text {-squared } \\
\text { Clusters }\end{array}$ & $\begin{array}{l}8,004 \\
0.35 \\
265\end{array}$ & $\begin{array}{l}7,4,735 \\
0.46 \\
158\end{array}$ & $\begin{array}{l}3,269 \\
0.51 \\
107\end{array}$ & $\begin{array}{l}4,641 \\
0.44 \\
157\end{array}$ & $\begin{array}{l}1,753 \\
0.61 \\
64\end{array}$ & $\begin{array}{l}2,888 \\
0.53 \\
93\end{array}$ & $\begin{array}{l}8,004 \\
0.35 \\
341\end{array}$ & $\begin{array}{l}4,735 \\
0.46 \\
210\end{array}$ & $\begin{array}{l}3,269 \\
0.51 \\
131\end{array}$ \\
\hline $\operatorname{Mean}\left(L_{i t}\right)$ & 0.378 & 0.374 & 0.383 & 0.378 & 0.374 & 0.383 & 0.378 & 0.374 & 0.383 \\
\hline
\end{tabular}

Notes: As before, the dependent variable is $L_{i t}=1$ if a firm $i$ receives a loan and $L_{i t}=0$ if a firm issues a bond in quarter $t$. If in a given quarter a firm did not have a new loan or bond issue, it is not included in the sample. The table reports results of the linear regressions. The focus is Domestic sovereign debt as a fraction of GDP. Domestic sovereign debt indicators in columns (7) to (9) are equal to one if sovereign debt is more than or equal to 60\%, but less than 90\%, of GDP; between 90\% and 120\% of GDP; and above 120\%. The omitted category is observations where Government debt is below $60 \%$ of GDP. Errors are heteroskedasticity-robust and clustered by country*year.

*** Significant at the 1 percent level.

** Significant at the 5 percent level.

* Significant at the 10 percent level. 